\title{
IGCC and PFBC By-Products: Generation, Characteristics and Management Practices
}

\author{
Topical Report \\ September 1997 \\ RECEIVED \\ By: \\ Debra F. Pflughoeft-Hassett \\ NOV 161998 \\ OQTI
}

Work Performed Under Contract No.: DE-FC21-93MC30097

For

U.S. Department of Energy

Office of Fossil Energy

Federal Energy Technology Center

P.O. Box 880

Morgantown, West Virginia 26507-0880

By

Energy \& Environmental Research Center

University of North Dakota

P. O. Box 9018

Grand Forks, North Dakota 58202-9018 


\section{Disclaimer}

This report was prepared as an account of work sponsored by an agency of the United States Government. Neither the United States Government nor any agency thereof, nor any of their employees, makes any warranty, express or implied, or assumes any legal liability or responsibility for the accuracy, completeness, or usefulness of any information, apparatus, product, or process disclosed, or represents that its use would not infringe privately owed rights. Reference herein to any specific commercial product, process, or service by trade name, trademark, manufacturer, or otherwise does not necessarily constitute or imply its endorsement, recommendation, or favoring by the United States Government or any agency thereof. The views and opinions of authors expressed herein do not necessarily state or reflect those of the United States Government or any agency thereof. 


\section{DISCLAIMER}

Portions of this document may be illegible in electronic image products. Images are produced from the best available original document. 


\section{LIST OF FIGURES}

1 Evolution of the coal-fired power plant $\ldots \ldots \ldots \ldots \ldots \ldots$

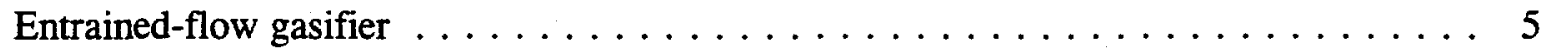

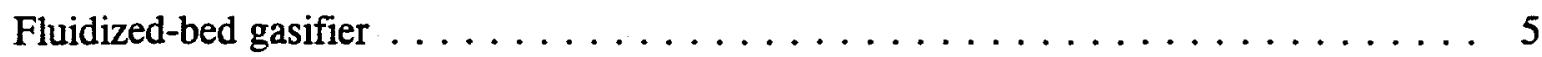

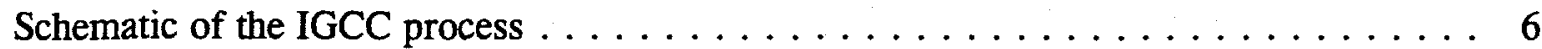

Schematic of circulating PFBC system $\ldots \ldots \ldots \ldots \ldots \ldots$

\section{LIST OF TABLES}

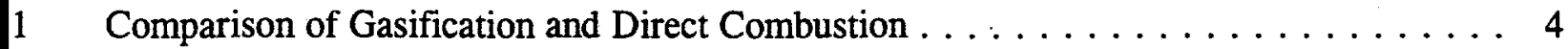

2 Summary of DOE IGCC Demonstration Projects $\ldots \ldots \ldots \ldots \ldots$

3 Summary of DOE PFBC Demonstration Projects $\ldots \ldots \ldots \ldots \ldots$

4 Summary of Leaching Data (inorganic constituents) on IGCC By-Products . . . . . . 12

5 Summary of Chemical Characterization Data for PFBC By-Products $\ldots \ldots \ldots \ldots$

6 Summary of Mineralogical Characterization Data for PFBC By-Products . . . . . . . 13

7 Summary of Leaching Characterization Data for PFBC By-Products . . . . . . . . . 14

8 Summary of Tampa Electric IGCC Project Commercial-Scale By-Product Data . . . . . 15

9 Comparison of Properties of IGCC Slag, Boiler Slag, and Bottom Ash . . . . . . . 16 


\section{IGCC AND PFBC BY-PRODUCTS: \\ GENERATION, CHARACTERISTICS, AND MANAGEMENT PRACTICES}

\section{PREFACE}

In July 1994, the U.S. Department of Energy (DOE) submitted a Report to Congress titled "Barriers to the Increased Utilization of Coal Combustion/Desulfurization By-Products by Governmental and Commercial Sectors." In this report, DOE made several recommendations for government actions, including recommendations for DOE itself. One of the recommendations that DOE charged itself with was to work with industry to contribute to a database addressing concerns relative to the Resource Conservation and Recovery Act (RCRA) regarding coal combustion byproducts derived from advanced coal technologies. DOE recognized the importance of working with industry and the U.S. Environmental Protection Agency (EPA) to facilitate appropriate regulations for clean coal technology (CCT) by-products and the importance of RCRA status for by-products relative to removing barriers to their utilization in both government and commercial sectors. Late in 1996, DOE contracted with the Energy \& Environmental Research Center (EERC) to prepare a report on CCT by-products to begin to fulfill DOE's own recommendations as stated in the 1994 Report to Congress. The report was to address the issues that EPA needed to review to make regulatory determinations on the status of fossil fuel combustion (FFC) wastes as mandated by the Bevill Amendment.

The following report is a compilation of data on by-products/wastes from clean coal technologies, specifically integrated gasification combined cycle (IGCC) and pressurized fluidizedbed combustion (PFBC). DOE had two objectives in providing this information to EPA: 1) to familiarize EPA with the DOE CCT program, CCT by-products, and the associated efforts by DOE contractors in the area of CCT by-product management and 2) to provide information that will facilitate EPA's effort by complementing similar reports from industry groups, including CIBO (Council of Industrial Boiler Owners) and EEI USWAG (Edison Electric Institute Utility Solid Waste Activities Group). The EERC cooperated and coordinated with DOE CCT contractors and industry groups to provide the most accurate and complete data on IGCC and PFBC by-products, although these technologies are only now being demonstrated on the commercial scale through the DOE CCT program.

In preliminary discussions with EPA regarding this report and the information being collected, EPA indicated an interest in reviewing the documentation with two primary objectives: 1) to compare the CCT by-products with other listed Bevill FFC wastes and 2) to develop an understanding of the need for continued review of by-products from developing technologies.

The EERC wishes to gratefully acknowledge the assistance of several individuals in the preparation of this report. Mr. Scott Renninger, DOE Federal Energy Technology Center (FETC), contracted with the EERC to perform this work and has provided direction and assistance regularly throughout the EERC's effort. Mr. Donald Bonk, Mr. Doug Jewell, Mr. Larry Carpenter, Mr. R. Daniel Brdar, and Mr. Robert Ruether, all of DOE, who explained projects to the contractor and provided project contacts. Mr. James Roewer, EEI USWAG Program Manager, provided contacts with industry and EPA. Mr. Robert Svendsen, CIBO and Foster Wheeler Power Systems, Inc., also provided industry and EPA contacts and shared information on fluidized-bed combustion 
(FBC) technology. Ms. Theresa Watley, Tampa Electric, provided information on IGCC processes and by-products, which ins included in the appendices and a tour of an IGCC facility. Ms. Sherry Dawes, Piñon Pine Production Manager, provided information on IGCC processes and byproducts, also included in the appendices. Mr. Joel Beeghly, Dravo Lime Company, provided information on atmospheric fluidized-bed combustion (AFBC) and PFBC by-products and management. Mr. Jim McClung, Foster Wheeler Development Corporation, provided information on the advanced PFBC plant that is currently in the developmental stages. Input from these individuals facilitated the preparation of this report and enhanced the contractor's understanding of government and industry issues. The EERC appreciated and enjoyed the opportunity to interact with these individuals.

The EERC research staff responsible for literature searches, literature review, data compilation, and interpretation are also gratefully acknowledged. These individuals were Mr. Kurt Eylands, Mr. David Hassett, Mr. Bruce Dockter, and Ms. Heather Holden. EERC Support staff Ms. Gayle Streier, Ms. Michelle Olderbak, and Ms. DeLoris Smith were also invaluable in assembling material for preparation of this document. 


AFBC
BGL
CATM
CCT
CIBO
DOE
EEI USWAG
EERC
EPA
FBC
FETC
FFC
IGCC
IGT
KRW
PCFB
PFBC
RCRA
TCLP

atmospheric fluidized-bed combustion

British Gas/Lurgi

Center for Air Toxic Metals

clean coal technology

Council of Industrial Boiler Owners

U.S. Department of Energy

Edison Electric Institute Utility Solid Waste Activities

Energy \& Environmental Research Center

U.S. Environmental Protection Agency

fluidized-bed combustion

Federal Energy Technology Center

fossil fuel combustion

Integrated Gasification Combined Cycle

Institute of Gas Technology

Kellogg Rust Westinghouse

pressurized circulating fluidized-bed combustion

pressurized fluidized-bed combustion

Resource Conservation and Recovery Act

toxicity characteristic leaching procedure 


\section{IGCC AND PFBC BY-PRODUCTS: GENERATION, CHARACTERISTICS, AND MANAGEMENT PRACTICES}

\subsection{INTRODUCTION TO DOE'S CLEAN COAL TECHNOLOGY PROGRAM}

The United States' Clean Coal Technology (CCT) Demonstration Program is a joint government-industry program representing an investment of more than $\$ 6.0$ billion. Initiated in January 1986, the program was developed based on recommendations made by the U.S. and Canadian Special Envoys on Acid Rain, with an early mandate to expand the menu of innovative pollution control options to curb the release of acid rain pollutants. The goal of the CCT program was to demonstrate the best of the innovative environmental technologies emerging from government and private coal research laboratories in the United States and elsewhere in the world.

The program was to be carried out in a series of competitions. Industry would propose the technologies it deemed ready for commercial-scale demonstration. The private sector, along with state governments, was asked to fund at least half the costs of projects selected, reinforcing the federal requirement that industry have sufficient confidence in the merits of prospective technologies.

The response of U.S. industry has been one of the major success stories of the public-private partnership. In fact, industry, in combination with state governments, has more than exceeded expectations. For the 40 projects currently in the program, investments from outside the federal government have totaled nearly $\$ 4.0$ billion. Today, nonfederal dollars account for $66 \%$ of the program's total costs.

Many of the first projects to be funded under the program, principally more cost-effective environmental retrofit technologies, are generating data or have finished their testing programs. Several projects, including low-polluting coal burners and postcombustion sulfur-removing devices, have moved into commercial application. Others are attracting growing interest overseas, particularly from developing nations looking for low-cost technology to bring older power facilities up to modern environmental standards.

While remaining within its original federal funding target, the program has broadened its objectives, and its 40 first-of-a-kind projects under way or completed in 18 states include an array of high-tech concepts that will pioneer the next generation of superclean, high-efficiency power plants. Now this next phase of the nation's investment in the CCT program is beginning to pay off. The larger projects, including demonstration of integrated gasification combined cycle (IGCC) and pressurized fluidized-bed combustion (PFBC), are completing their designs and moving into field construction. Data are being generated at several commercial-scale CCT facilities.

IGCC and PFBC combustors will reduce air emissions to only a fraction of those given off by today's technology while supplying affordable electric power. Through higher coal-toelectricity efficiencies, these projects are also addressing the growing global concern over greenhouse gas emissions. Nearly 900 megawatts (MWe) of new capacity and more than $800 \mathrm{MWe}$ of repowered capacity are represented by 12 projects valued at nearly $\$ 3.4$ billion. These include five fluidized-bed combustion (FBC) systems, four IGCC systems, and three advanced combustion/ 
heat engine systems. The projects will provide environmentally sound electric power generation and the demonstrated technology base to meet new capacity requirements in the future.

Government and industry have set an example of "learning by doing" to develop technology for the 21st century that will help fuel an expanding domestic and global economy while meeting the most rigorous of environmental standards. As a direct result of the Department of Energy (DOE) CCT program, the United States will have a new fleet of prototype demonstration power systems. It is important to note that these technologies were primarily developed to address U.S. Environmental Protection Agency (EPA) air emission issues, but in the technology development phases of these projects, the partners chose to address solid waste issues as well. These projects represent what are currently considered emerging technologies, but because of the numerous improvements over conventional coal use technology in efficiency, level of emissions, and solid waste issues, DOE and the project partners envision these as the technologies of choice for the near future.

Information on the characteristics and management of by-products from several DOE CCT projects is included in this report. It is important to note that for this report, the term by-product is used because the CCT projects discussed include utilization as a management option for the solid waste generated. In common utility waste management usage, by-product denotes a utilized material while waste generally refers to materials that require disposal. Disposal is not generally the preferred option for CCT "wastes," and the projects presented focus on the utilization potential of solids generated because it is the preferred option. Four of the projects have been completed or are in the commercial-scale phase, so information on laboratory-, pilot-, and commercial-scale tests is all included. The fifth project (the Lakeland PFBC project) has not yet reached commercial scale, so only limited information is provided.

The DOE CCT projects demonstrating PFBC and IGCC discussed here are as follows:

- The Tidd Project (PFBC) - The Ohio Power Company, Brilliant, Ohio

- Pressurized Circulating Fluidized--ed Demonstration Project - Lakeland Department of Electric \& Water, Lakeland, Florida

- Tampa Electric IGCC Project - Tampa Electric Company, Tampa, Florida

- Piñon Pine IGCC Power Plant - Sierra Pacific Power Company, Reno, Nevada

- Wabash River Coal Gasification Repowering Project - Wabash River Coal Gasification Repowering Project Joint Venture, West Terre Haute, Indiana

\subsection{IGCC AND PFBC PROCESSES AND ASSOCIATED BY-PRODUCTS}

Conventional technology used in coal-fired electric power generation is based on the use of steam turbines. These systems are nearing their theoretical efficiency limit (Rankine barrier), and powerful driving forces are pushing for development of advanced coal-fired power systems to improve cost, efficiency, and environmental compliance. Advanced clean coal technologies, 
including PFBC and IGCC, are being introduced at the commercial demonstration scale through the DOE Fossil Energy Clean Coal Technology Program. These technologies make it possible to use the vast reserves of coal in the United States for efficient and environmentally clean energy production. Coal-fired combined cycle efficiencies are projected to evolve toward a level of about $50 \%$ efficiency, based principally on various means for achieving higher gas turbine temperatures with hot-gas cleanup, but also on the use of supercritical steam generators in heat recovery. Real potential exists to increase efficiencies from today's limit of $37 \%$ to efficiencies approaching $60 \%$ by the year 2020 (Douglas, 1990) through the use of integrated gasification power plants with advanced gas turbines or molten carbonate fuel cells. The evolution of coal-fired power plants is illustrated in Figure 1.

\subsection{Integrated Gasification Combined Cycle}

Coal gasification has been technically and economically feasible for many years. Coal gasification can be compared to fuel-rich coal combustion. Essentially the same physical and chemical processes occur during gasification and direct combustion. The similarities between gasification and direct combustion include fuel preparation and grinding, which is important to note relative to waste management. The interactions of the processes common to gasification and direct combustion are different, and the results are different as well. Table 1 gives a comparison of the processes for gasification and direct combustion.

In coal gasification systems, the coal is converted to a combustible gas, volatiles, char, and ash/slag. Commercial gasifiers differ widely in the way in which they produce ash, and either a dry ash, agglomerated ash, or slag may result. Fixed-bed gasifiers operate by passing air or oxygen and steam under pressure up through a bed of coal, which is fed to the top of the bed through a lock

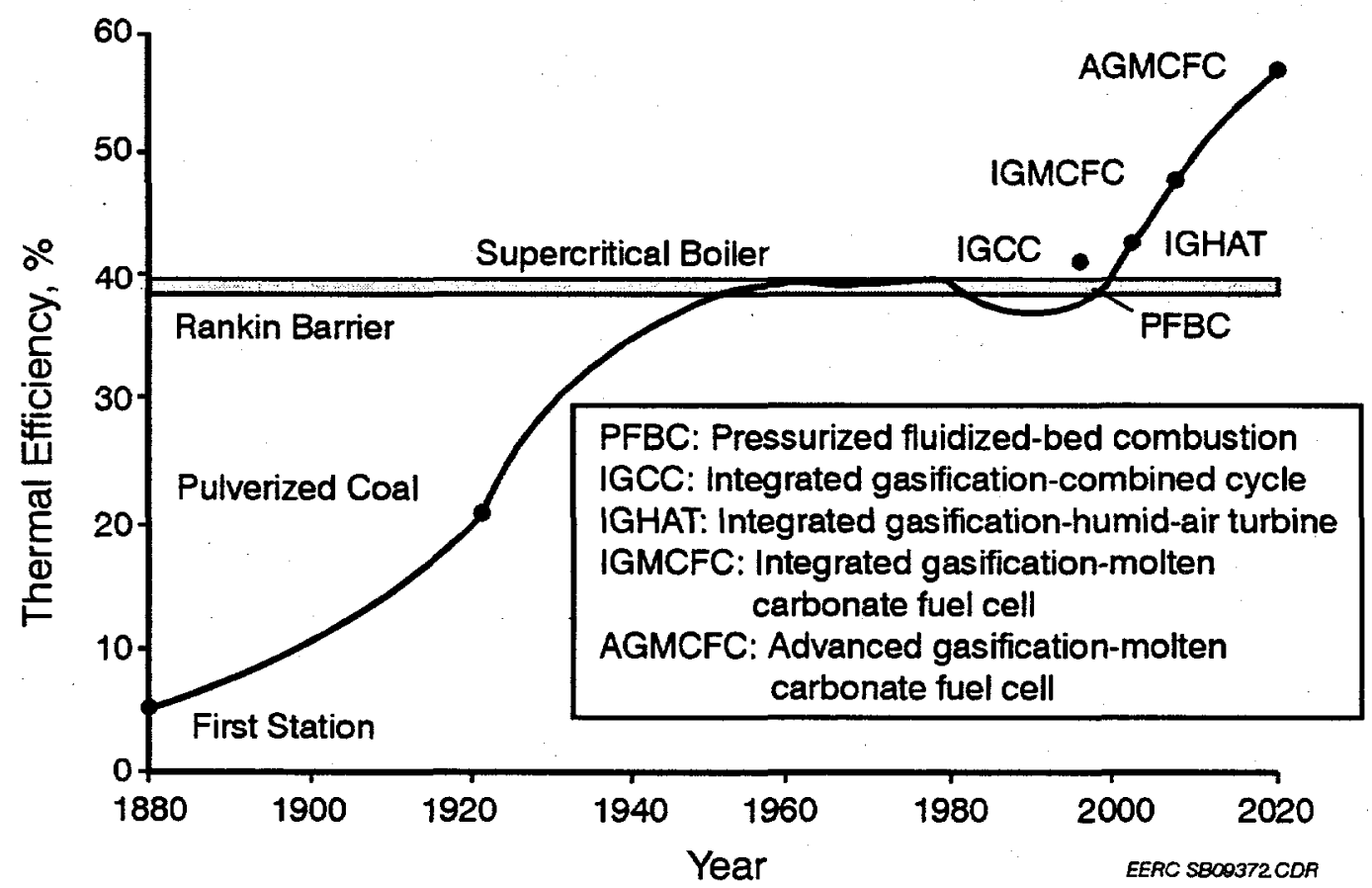

Figure 1. Evolution of the coal-fired power plant (Douglas, 1990). 
TABLE 1

Comparison of Gasification and Direct Combustion ${ }^{1}$

\begin{tabular}{lcc}
\hline & Direct Coal Combustion & Coal Gasification \\
\hline Operating Temperature & Lower & Higher \\
Operating Pressure & Usually atmospheric & Often high-pressure \\
Ash Condition & Often dry & Often slagging \\
Feed Gases & Air & Steam, oxygen \\
Product Gases & $\mathrm{CO}_{2}, \mathrm{H}_{2} \mathrm{O}$ & $\mathrm{CO}, \mathrm{H}_{2}, \mathrm{CH}_{4}, \mathrm{CO}_{2}, \mathrm{H}_{2} \mathrm{O}$ \\
Gas Cleanup & Postscrubbing $_{2}$ & Intermediate scrubbing \\
Pollutants & $\mathrm{SO}_{2}, \mathrm{NO}_{x}$ & $\mathrm{H}_{2} \mathrm{~S}, \mathrm{HCN} \mathrm{NH}_{3}$ \\
Char Reaction Rate & Fast (with $\mathrm{O}_{2}$ ) & Slow (with $\mathrm{CO}_{2}, \mathrm{H}_{2} \mathrm{O}$ ) \\
Oxidizer & In excess & Deficient \\
Tar Production & None & Sometimes \\
Purpose & High-temperature & Fuel-rich gas \\
\hline
\end{tabular}

${ }^{1}$ After Smoot and Smith, 1985.

hopper. Coal and char move to the bottom as they are gasified, and the dry ash is removed through a bottom grate. Alternatively, a fixed-bed gasifier can be designed to operate at high temperatures, producing a bottom slag that is tapped through a hearth, i.e., the British Gas/Lurgi (BGL) process. Fluidized-bed gasifiers, including the U.S. Kellogg Rust Westinghouse (KRW) and Institute of Gas Technology (IGT) processes and the German Winkler process, operate in a gasification mode using steam and air or oxygen in a fashion resembling PFBC. Either dry ash or a fused agglomerated ash may be produced depending on the design, operating temperatures, and fusion temperature of the ash. Entrained-flow gasifiers, including Destec Energy Inc, Texaco, and Shell designs, all operate at very high temperatures and produce a vitreous slag. IGCC systems directly link these various types of gasifiers with a gas turbine/steam turbine cycle to achieve high conversion efficiency. IGCC is being demonstrated on the commercial scale in three major joint projects between DOE and industry. These commercial IGCC demonstrations represent the entrained-flow gasifier (two sites) and the fluidized-bed gasifier (one site). A diagrammatic representation of an entrained-flow gasifier is shown in Figure 2 and a similar representation for a fluidized-bed gasifier in Figure 3. A schematic of IGCC is shown in Figure 4, which includes lists of the potential by-product streams.

The by-products formed in these IGCC processes can be better understood in the context of the process and operating variables. Table 2 provides key information relative to the specific process for each of the three commercial-scale IGCC demonstration sites in the United States. It is important to note that the by-product streams are not the same for each process. The products of these processed by-products are listed separately in the table. Also important to note, the by-products have generally been designed to be utilized rather than disposed of as part of the overall project plan. 


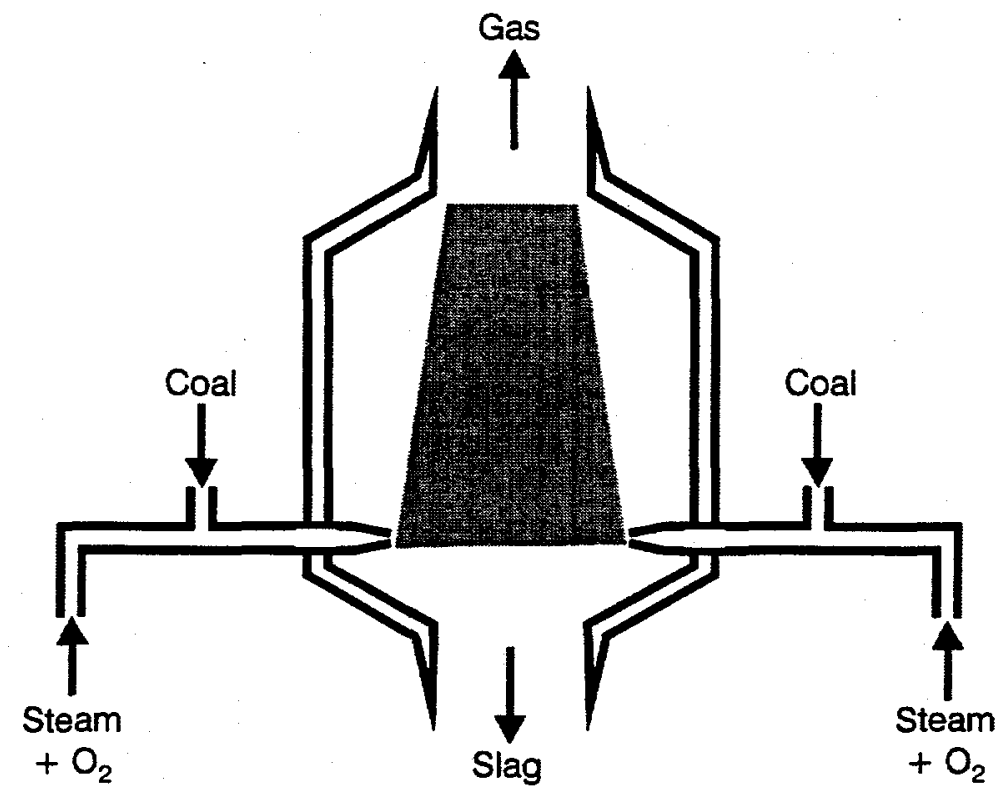

Entrained Flow

$1250^{\circ}-1900^{\circ} \mathrm{C}$

EERC DPH14313.CDR

Figure 2. Entrained-flow gasifier (up-flow).

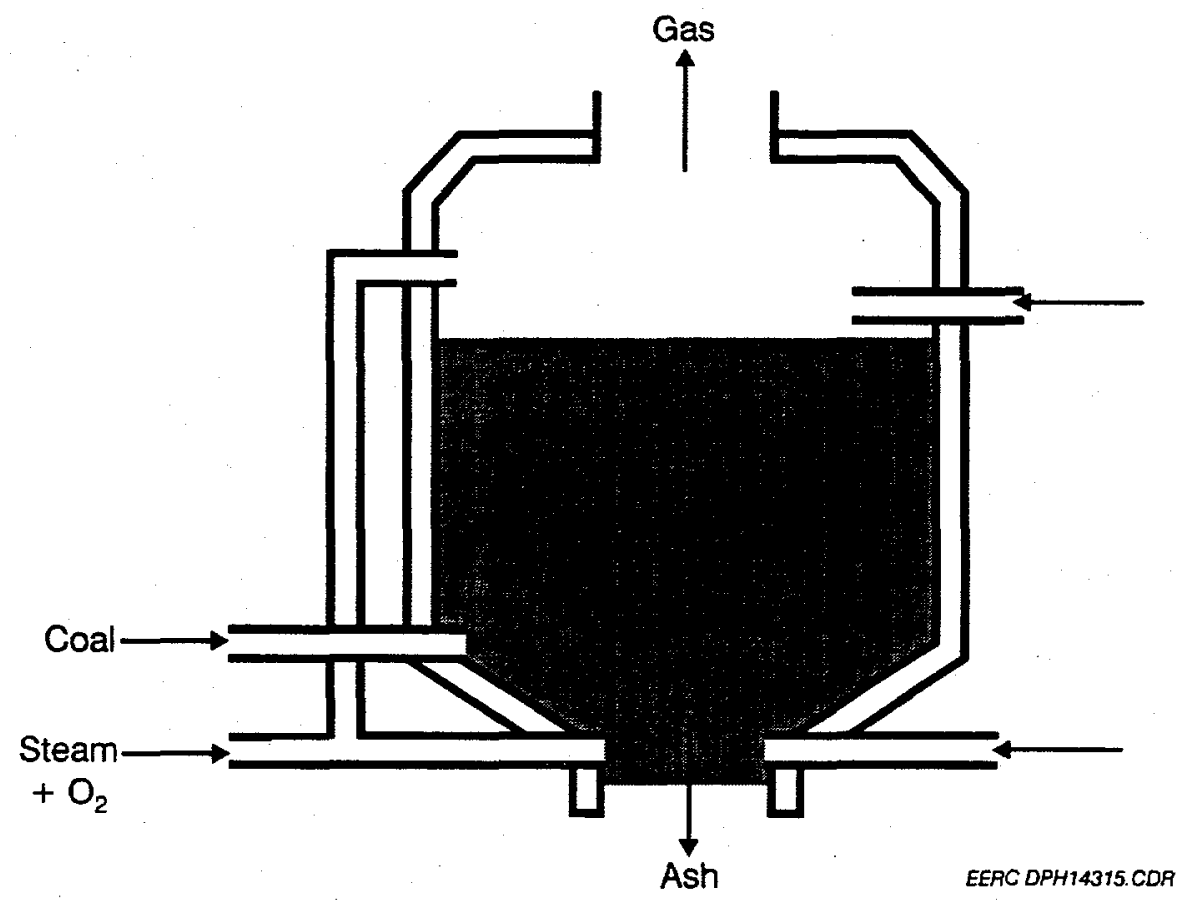

Figure 3. Fluidized-bed gasifier. 


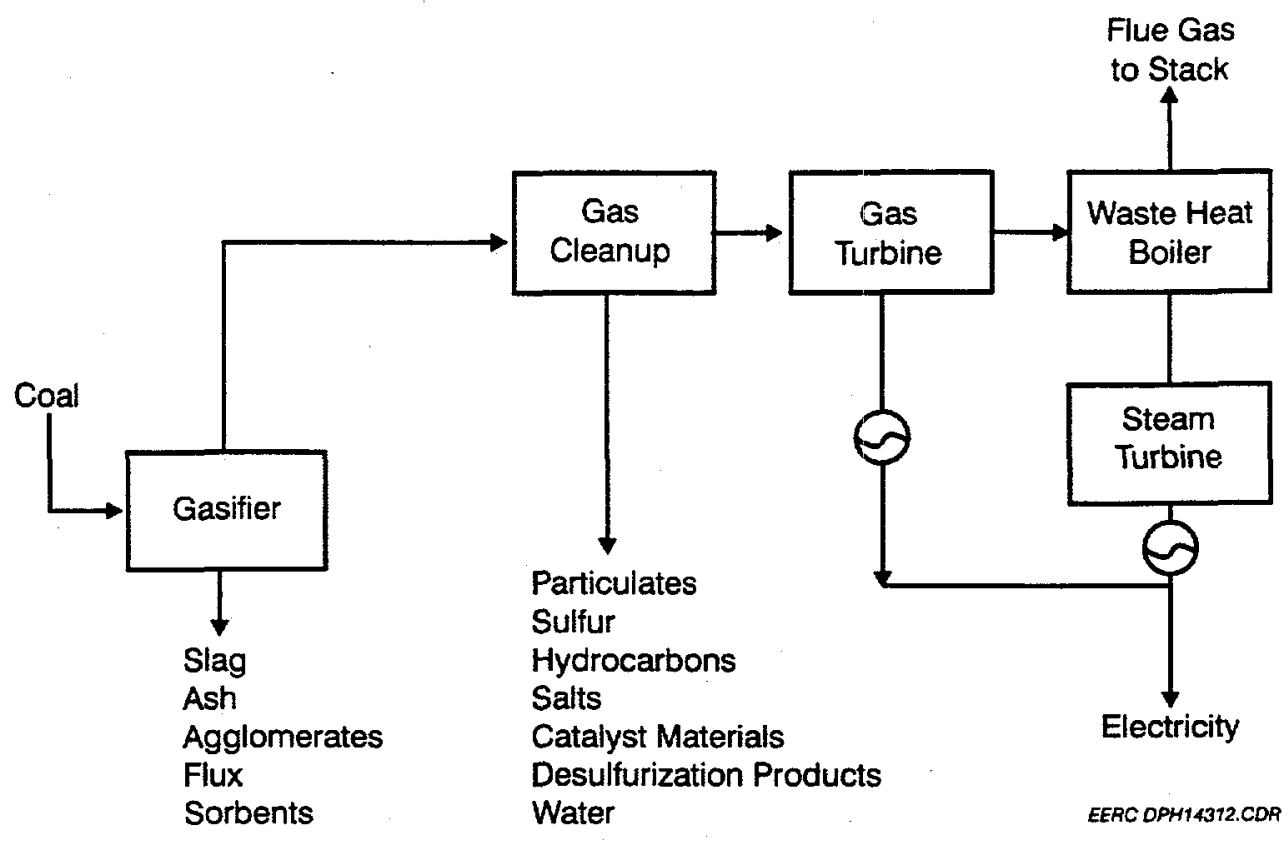

Figure 4. Schematic of the IGCC process.

The entrained-flow gasifier or slagging gasifier is being demonstrated at the commercial-scale at 2 sites under the DOE CCT program. The Destec process and the Texaco process are examples of entrained-flow gasifiers incorporating the combined cycle process for gas cleanup, gas turbine, and steam turbine for efficient production of electricity.

\subsection{Summary of By-Products from IGCC}

The chemical, mineralogical, and physical characteristics of gasifier by-products have been investigated (Eklund, 1986; McCarthy and others, 1985; Stevenson and Larson, 1985; Hassett and others, 1985), and the characteristics of IGCC by-products produced from the Shell pilot-scale testing (Mahagaokar and others, 1990) and Texaco testing (EPRI, 1990) have been reported. Slag/ash samples have been characterized from eight gasifiers (Eklund, 1986). The types of materials examined included coarse ash or slag and cyclone dust. The materials were found to be nonhazardous, but the physical characteristics and chemical compositions varied significantly as a function of process configuration, operation, coal feed composition, and coal handling, similarly to the compositional variations noted for pulverized coal combustion by-products. The elemental compositions of the slags produced in gasification systems were similar to that of the bottom ash from conventional coal combustion systems (Turner and Lowry, 1983). The bulk compositions of cyclone dust samples were found to be similar to that of conventional coal combustion fly ash (Wetzel and others,-1982). Mineralogical examination of slags (McCarthy and others, 1985) indicated that many of the same high-temperature silicate minerals are present in the slag samples along with reduced iron-bearing compounds. The key difference in coal gasification ash and slag compared to combustion ash is the lack of sulfur. Sulfur is present in small quantities in the ash, and depending on the process may be present as sulfide, sulfate, or sulfite. In addition, the other elemental species in the system may also be in reduced form. The entrained-flow slagging gasifiers recycle fly ash back to the vitreous slag. Slag samples produced in the Shell process (Mahagaokar and others, 1990) were shown to be depleted in several trace elements. 
TABLE 2

Summary of DOE IGCC Demonstration Projects

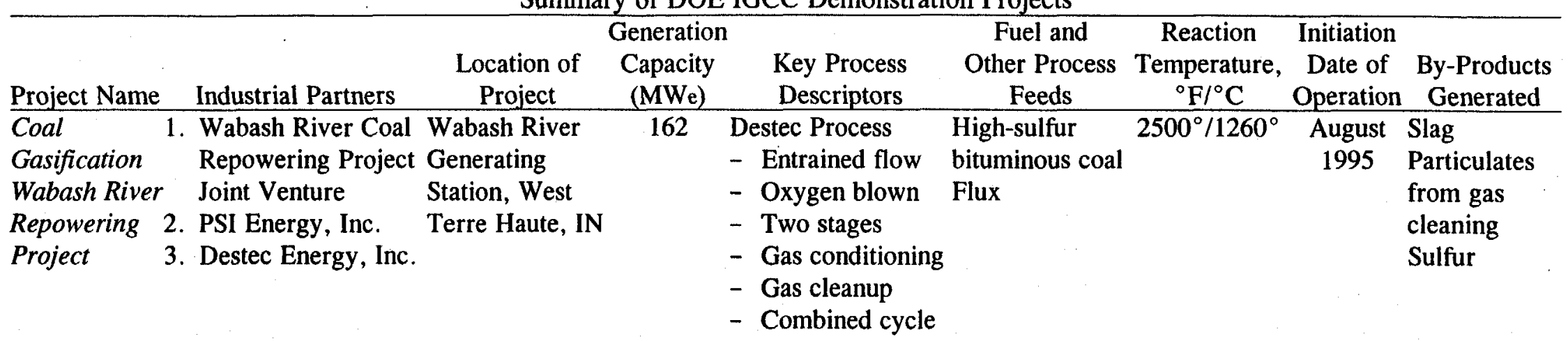

\begin{tabular}{|c|c|c|c|c|c|c|c|c|}
\hline $\begin{array}{l}\text { Tampa } \\
\text { Electric } \\
\text { Integrated } \\
\text { Gasification } \\
\text { Combined- } \\
\text { Cycle Project }\end{array}$ & $\begin{array}{l}\text { 1. Tampa Electric } \\
\text { Company } \\
\text { 2. Texaco } \\
\text { Development } \\
\text { Corporation } \\
\text { 3. General Electric } \\
\text { Corporation } \\
\text { 4. Air Products and } \\
\text { Chemical, Inc. } \\
\text { 5. Bechtel Corporation }\end{array}$ & $\begin{array}{l}\text { Polk County } \\
\text { Plant, } \\
\text { Mulberry, FL }\end{array}$ & 250 & $\begin{array}{l}\text { Texaco Process } \\
\text { - Entrained flow } \\
\text { - Oxygen blown } \\
\text { - Single stage } \\
\text { - Downward firing } \\
\text { - Hot-gas cleanup } \\
\text { - Combined cycle }\end{array}$ & $\begin{array}{l}\text { Eastern U.S. } \\
\text { bituminous coal } \\
\text { Oxygen } \\
\text { Slurry water } \\
\text { Nitrogen }\end{array}$ & $\begin{array}{c}2500-2700 / \\
1260-1450\end{array}$ & $\begin{array}{c}\text { October } \\
1996\end{array}$ & $\begin{array}{l}\text { Ammonium } \\
\text { chloride } \\
\text { Sulfuric acid } \\
\text { Solidified } \\
\text { slag }\end{array}$ \\
\hline $\begin{array}{l}\text { Piñon Pine } \\
\text { Power } \\
\text { Project }\end{array}$ & $\begin{array}{l}\text { 1. Sierra Pacific Powe } \\
\text { Company } \\
\text { 2. Foster Wheeler } \\
\text { Development } \\
\text { Corporation } \\
\text { 3. M.W. Kellogg } \\
\text { Company }\end{array}$ & $\begin{array}{l}\text { Tracy Power } \\
\text { Plant, Stoney } \\
\text { County, near } \\
\text { Reno, NV }\end{array}$ & 100 & $\begin{array}{l}\text { KRW Process } \\
\text { - Pressurized } \\
\text { fluidized bed } \\
\text { - Air blown } \\
\text { - Hot-gas cleanup } \\
\text { - Combined cycle }\end{array}$ & $\begin{array}{l}\text { Low-sulfur } \\
\text { bituminous coal } \\
\text { Limestone } \\
\text { Steam } \\
\text { Air }\end{array}$ & $1800 / 982$ & $\begin{array}{c}\text { November } \\
1997\end{array}$ & $\begin{array}{l}\text { rLASH, } \\
\text { combination } \\
\text { of excess } \\
\text { limestone, } \\
\text { lime, ash, } \\
\text { and } \mathrm{CaSO}_{4}\end{array}$ \\
\hline
\end{tabular}


TABLE 3

Summary of DOE PFBC Demonstration Projects

\begin{tabular}{|c|c|c|c|c|c|c|c|}
\hline Project Name & Industry Partners & $\begin{array}{c}\text { Location of } \\
\text { Project }\end{array}$ & $\begin{array}{c}\text { Generating } \\
\text { Capacity } \\
\text { (MWe) } \\
\end{array}$ & $\begin{array}{c}\text { Key Process } \\
\text { Descriptors }\end{array}$ & $\begin{array}{l}\text { Fuel and Other } \\
\text { Process Feeds }\end{array}$ & $\begin{array}{l}\text { Dates of } \\
\text { Operation }\end{array}$ & $\begin{array}{c}\text { By-Products } \\
\text { Generated }\end{array}$ \\
\hline $\begin{array}{l}\text { Tidd } \\
\text { Pressurized } \\
\text { Fluidized-Bed } \\
\text { Coal } \\
\text { Technologies } \\
\text { Project }\end{array}$ & $\begin{array}{l}\text { 1. Ohio Power } \\
\text { Company } \\
\text { 2. American } \\
\text { Electric Power } \\
\text { Service } \\
\text { Corporation } \\
\text { 3. Babcock \& } \\
\text { Wilcox } \\
\text { 4. Ohio Coal } \\
\text { Development } \\
\text { Office }\end{array}$ & Brilliant, $\mathrm{OH}$ & 70 & $\begin{array}{l}\text { First-generation PFB } \\
\text { Bubbling bed boiler } \\
\text { Gas cleanup } \\
\text { Gas and steam turbine }\end{array}$ & $\begin{array}{l}\text { Ohio bituminous } \\
\text { coal }(2 \%-4 \% \\
\text { sulfur }) \\
\text { Dolomite }\end{array}$ & $\begin{array}{l}\text { October } 1990- \\
\text { March } 1995\end{array}$ & $\begin{array}{l}\text { Spent bed } \\
\text { material } \\
\text { Cyclone ash } \\
\text { Precipitator } \\
\text { ash }\end{array}$ \\
\hline $\begin{array}{l}\text { Lakeland } \\
\text { PCFB Project }\end{array}$ & $\begin{array}{l}\text { 1. City of } \\
\text { Lakeland } \\
\text { 2. Foster Wheeler } \\
\text { Energy } \\
\text { Corporation } \\
\text { 3. Westinghouse } \\
\text { Electric } \\
\text { Corporation }\end{array}$ & $\begin{array}{l}\text { McIntosh } \\
\text { Power Station, } \\
\text { Lakeland, FL }\end{array}$ & $160-170$ & $\begin{array}{l}\text { Second-generation } \\
\text { PFB } \\
\text { Circulating bed } \\
\text { (untopped) } \\
\text { Circulating bed } \\
\text { (topped with } \\
\text { carbonizer) }\end{array}$ & $\begin{array}{l}\text { Coal } \\
\text { Bed material }\end{array}$ & $\begin{array}{l}\text { Approximately } \\
2000 \\
\text { (untopped) } \\
\text { Approximately. } \\
2002 \text { (topped) }\end{array}$ & $\begin{array}{l}\text { Spent bed } \\
\text { material } \\
\text { Fine } \\
\text { particulates } \\
\text { Calcium } \\
\text { sulfate }\end{array}$ \\
\hline
\end{tabular}


In gasification systems, sulfur recovery units are used to remove sulfur to convert it to sulfuric acid or elemental sulfur. Alternatively, or as a complement to a sulfur recovery system, reduced forms of sulfur can be oxidized and removed with a calcium-based sorbent in the form of calcium sulfate. Fluidized-bed gasifiers that incorporate in situ sulfur capture produce calcium sulfide that must be oxidized to sulfate before it is suitable for either use or disposal.

Specific characteristics of IGCC by-products and management practices are included in Sections 3.0-5.0 of this report.

\subsection{Pressurized Fluidized-Bed Combustion}

The fluidized-bed combustion (FBC) process consists of two subprocesses: 1) the fluidization of solids, by which solid particles/granules are suspended in an upward flowing stream of gas and 2) the combustion process, in which fuel particles are burned to sustain temperature. The solids in FBCs are typically fuel ash, bed material, sorbent used to control pollutants, and reaction products formed by sulfur capture and other sorbent-coal interactions. FBC systems operated at atmospheric pressure are classified as atmospheric fluidized-bed combustors (AFBCs), which usually also denotes low fluidization velocities resulting in a bubbling bed. Circulating fluidized-bed combustors (CFBCs) operate at fluidization velocities approximately 7 to 8 times higher. At these velocities, the rising gas entrains the bed materials; the resulting bed consists of a turbulent cloud of solids that fills the combustion chamber. A portion of the bed material is continuously carried out with the offgas and recirculated to the combustion chamber. PFBC systems are similar to AFBCs but operate under pressure. The compressed air used contains more oxygen per unit volume and, therefore, sustains a higher intensity of combustion, allowing for the design of smaller combustors. The other principal advantage of the PFBC is the increased conversion efficiency (coal-to-electricity) that can be achieved by passing the hot, pressurized combustion gases through both a gas turbine and a waste heat boiler serving a steam turbine to extract more useable energy in a combined-cycle system.

Under the DOE's CCT program, PFBC technology has been investigated, and demonstration of commercial-scale systems is included in those investigations. The current terminology applied to PFBC technologies are "first-generation PFBC" and "second-generation PFBC." The firstgeneration PFBC technology was demonstrated at the Tidd Pressurized Fluidized-Bed Coal Technologies Project, which is summarized in Table 3. Successful demonstration of the PFBC technology at that site was encouraging, and two additional DOE PFBC demonstration projects were planned. These were proposed for sites in Iowa and Kentucky, but because of uncertainties regarding regional power requirements, these two projects were combined into a demonstration of second-generation PFBC technology, basically combining the high-tech pressurized circulating fluidized-bed (PCFB) combustor, which captures sulfur and other pollutants from the coal fuel, and the production of high-pressure coal gases that can power a combined cycle gas and steam turbine similar to that used by IGCC. If the PCFB technology is successful alone based on tests scheduled to begin in 2000 , it is proposed to add another advanced technology to the system. This will be a carbonizer added to the coal-burning process to produce fuel gas and char from coal. The char will be fed with fresh coal to the PCFB combustor, and the gas will be cleaned and fed to a topping combustor to drive the gas turbine. This addition is expected to increase the efficiency of the system up to approximately $46 \%$ and add another 12 megawatts of power output. This demonstration planned for Lakeland, Florida, is summarized in Table 3. 


\subsection{Summary of By-Products from PFBC}

The characteristics of the solid residues produced in FBCs depend on the bed material, fuel and ash compositions, unburnt carbon, desulfurization products, and unreacted sorbents. The residues can be collected from several locations in the system, including the bed offtake, primary cyclone, and final particulate control device. The quantity of the residues depends on the coal characteristics. High-sulfur coals require more sorbent to collect $\mathrm{SO}_{2}$. Certain high-sodium western coals require high bed turnover rates to minimize bed agglomerations (Mann and others, 1992).

By-products from PFBC include coal ash, unburned carbon, desulfurization products (spent sorbent), and unreacted sorbent. These facilities generate a fly ash that is generally a combination fine, lightweight coal ash and fine bed material (including both spent bed and unreacted sorbent). Coal ash, unburned carbon, spent sorbent, and unreacted sorbent may contribute to the composition of the spent bed material. The spent sorbent contains a sulfur component, which is generally calcium sulfite. Unburned carbon is generally minimal in these systems, as they are designed for high efficiency, and generally a longer residence time in any FBC system provides adequate time and temperature for complete combustion. A schematic of a circulating PFBC system is shown in Figure 5. Approximations of by-product proportions are also indicated in Figure 5. As with all coal conversion processes, the specific characteristics of the various by-products is dependent on the fuel source, bed material, system configuration, and operating parameters. Further detail on the characteristics of PFBC is included in Sections 3.0-5.0 of this report and the appendices.

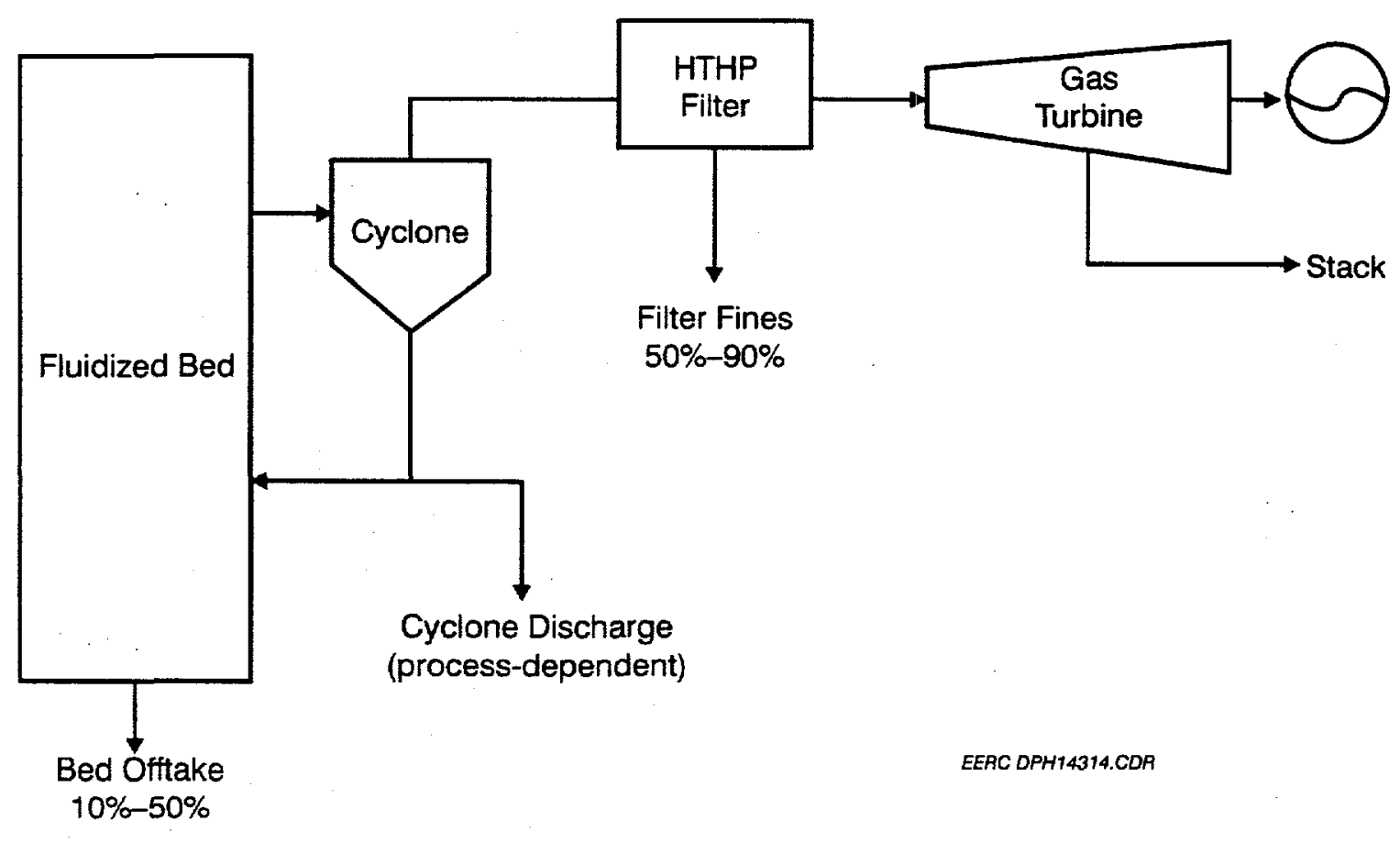

Figure 5. Schematic of circulating PFBC system. 


\subsection{SUMMARY OF BENCH- AND PILOT-SCALE-GENERATED BY-PRODUCT CHARACTERISTICS}

The technologies discussed in this report are best described as emerging commercial-scale technologies and were developed as one DOE-industry response to the mandate to expand the menu of innovative pollution control options to curb the release of acid rain pollutants. These technologies also offer improved efficiency for energy production from coal. In the technology development phases of the DOE CCT projects and similar projects elsewhere, solid waste issues have been evaluated at varying levels. Bench- and pilot-scale experiments and demonstrations were a necessary step in the development of these technologies and provided the information required to continue development into the commercial-scale demonstration phase. By-product characteristics and management are currently being assessed as part of each commercial-scale project.

Numerous summary reports of the bench- and pilot-scale phases of CCT development are available and were used to assemble information on CCT by-product characteristics. Detailed information on the by-products generated and tested in the bench- and pilot-scale technology demonstrations are included in Appendices A and B.

\subsection{Integrated Gasification Combined Cycle}

The by-products from IGCC that are analogous to fossil fuel combustion wastes are IGCC slag, fine particulates, fly ash, spent sorbent, and, in some cases, combinations of these streams. The specific by-product streams vary based on the specific IGCC process. IGCC slag is generally the highest-volume by-product of the various IGCC processes, and based on available literature on the bench- and pilot-scale IGCC experiments, the most characterization data were available for this by-product. Only limited characterization information is reported in literature on other bench- and pilot-scale IGCC by-products. A compilation of the available characterization data is included in Appendix A.

The types of information that were obtained and reviewed varied broadly and included bulk chemical composition, leachate composition, size distribution, density, and specific gravity. These data provide information relative to the potential environmental behavior of the materials as well as giving an indication of appropriate management practices for the individual by-products. Chemical composition of the IGCC by-products varied widely, and numerous trace constituents were found to be present in these by-products at very low levels. This is common in any coal use byproduct because of the variability of the composition of the coal and other process inputs.

Coal has been shown to contain constituents that are of concern relative to the Resource Conservation and Recovery Act (RCRA), and it can be expected that these constituents may be present in the coal use by-products. On review of the published leaching data for bench- and pilotscale-generated IGCC by-products, it was observed that there were no cases where leachate concentrations of any RCRA constituents were measured to be above the action limits established by RCRA.

A summary of IGCC by-product/waste leaching characterization (inorganic constituents) data is shown in Table 4. By-product data ranges for specific types of IGCC systems are given. These 
Summary of Leaching Data (inorganic constituents) on IGCC By-Products, mg/L

\begin{tabular}{lcccccc}
\hline & $\begin{array}{c}\text { Commercial- } \\
\text { Scale IGCC } \\
\text { Slag }\end{array}$ & $\begin{array}{c}\text { Bench-Scale } \\
\text { IGCC Slag }\end{array}$ & $\begin{array}{c}\text { Bench-Scale } \\
\text { Scrubber Filter } \\
\text { Cake }\end{array}$ & $\begin{array}{c}\text { Fine } \\
\text { Particulate }\end{array}$ & $\begin{array}{c}\text { Bench-Scale Spent } \\
\text { Bed Material and RCRA } \\
\text { Ash Mixture }\end{array}$ & $\begin{array}{c}\text { Rimits } \\
\text { Lim }\end{array}$ \\
\hline $\mathrm{Ag}$ & $<0.01$ & $<0.001-0.001$ & $<0.001-0.002$ & $<0.001-0.001$ & $\leq 0.005$ & 5 \\
$\mathrm{As}$ & $<0.02$ & $<0.001-<0.06$ & $0.001-0.039$ & $0.001-0.014$ & 0.015 & 5 \\
$\mathrm{Ba}$ & $0.32-0.43$ & $<0.001-0.402$ & $0.16-0.17$ & 0.24 & 0.33 & 100 \\
$\mathrm{Cd}$ & $<0.01-0.02$ & $<0.001-0.013$ & $<0.001-0.054$ & $0.15-0.21$ & 0.02 & 1 \\
$\mathrm{Cr}$ & $<0.01$ & $<0.001-0.053$ & $<0.001-0.0047$ & $<0.001-0.0016$ & 0.36 & 5 \\
$\mathrm{Hg}$ & $\mathrm{NA}$ & $<0.001-0.001$ & $<0.001-0.068$ & $<0.001-0.001$ & 0.0041 & 0.2 \\
$\mathrm{~Pb}$ & $<0.05$ & $<0.001-0.08$ & $<0.001-0.068$ & $0.001-0.0038$ & $\leq 0.02$ & 5 \\
$\mathrm{Se}$ & $<0.02$ & $<0.001-<0.08$ & $0.001-0.013$ & $0.001-0.006$ & $\leq 0.02$ & 1 \\
\hline
\end{tabular}

* Leaching tests vary. See Appendix A for detailed data.

NA - Not available.

data include information on different coal sources. The data reported in Table 4 and in Appendices $\mathrm{A}$ and $\mathrm{C}$ indicates that IGCC slags are essentially non-leaching materials.

\subsection{Pressurized Fluidized-Bed Combustion}

As noted in Section 2.0, first-generation PFBC technology has been demonstrated on the commercial scale at the DOE Tidd CCT Project (Henderson, 1991; Mudd, 1989). The wastelike by-products from PFBC are high-calcium (or calcium-magnesium) and sulfur spent bed material and particulates collected from cyclones or precipitators. The characteristics and behavior of the byproducts from the Tidd demonstration are extensive and widely published. The published data on bench- and pilot-scale-generated PFBC by-products are shown in Appendix B. A summary of these data is given in Tables 5 through 7 . Leaching data summarized in Table 7 indicate that the byproduct is not hazardous based on RCRA limits and therefore appropriate for utilization. The tables also show information on atmospheric fluidized-bed combustion (AFBC) systems for comparison.

Second-generation, or advanced, PFBC technology will be demonstrated in Lakeland, Florida, as part of the DOE CCT program. The technology is summarized in several reports (McClung and others, 1995, 1997; Domeracki and others, 1997), and the process will be demonstrated at a $7-\mathrm{MW}$ scale at a facility in Wilsonville, Alabama, as part of the DOE CCT project.

\subsection{SUMMARY OF COMMERCIAL-SCALE GENERATED BY-PRODUCT CHARACTERISTICS}

The commercial demonstration of the DOE CCT projects is the culmination of the CCT program and is still in progress. Several projects have recently begun operation on the commercial scale. These are a follows: 
- Tampa Electric IGCC Project - Tampa Electric Company, Tampa, Florida

- Piñon Pine IGCC Power Plant - Sierra Pacific Power Company, Reno, Nevada

- Wabash River Coal Gasification Repowering Project - Wabash River Coal Gasification Repowering Project Joint Venture, West Terre Haute, Indiana

One project has been completed:

- The Tidd Project (PFBC) - The Ohio Power Company, Brilliant, Ohio

And one has been permitted but not yet constructed:

- Pressurized Circulating Fluidized-Bed Demonstration Project - Lakeland Department of Electric \& Water, Lakeland, Florida

TABLE 5

Summary of Chemical Characterization Data for PFBC By-Products, \%

\begin{tabular}{lccc}
\hline & AFBC & PFBC - Pilot & PFBC - Commercial \\
\hline $\mathrm{SiO}_{2}$ & $4.7-29.3$ & $25.4-28.4$ & $19.93-23.76$ \\
$\mathrm{Al}_{2} \mathrm{O}_{3}$ & $1.89-16.3$ & $11.9-13.4$ & $7.75-11.6$ \\
$\mathrm{Fe}_{2} \mathrm{O}_{3}$ & $2.14-7.29$ & $5.0-8.4$ & $9.02-13.28$ \\
$\mathrm{CaO}$ & $24.92-56.14$ & $12.1-21.5$ & $19.4-22.13$ \\
$\mathrm{MgO}$ & $0.06-25.12$ & $8.1-14.2$ & $10.61-14.38$ \\
$\mathrm{Na}$ & $0.19-0.6$ & $0.4-1.0$ & NA \\
$\mathrm{SO}_{3}$ & $14.5-92.5$ & $11.5-23.3$ & $8.69-12.46$ \\
$\mathrm{P}_{2} \mathrm{O}_{5}$ & $0.002-0.175$ & 0.1 & NA \\
$\mathrm{BaO}$ & $\mathrm{NA}$ & $0.0-0.2$ & $<0.5-<1$ \\
\hline
\end{tabular}

* Not available.

\section{TABLE 6}

Summary of Mineralogical Characterization Data for PFBC By-Products, \% (average of all by-product types)

\begin{tabular}{lcc}
\hline Mineral Analysis & AFBC $($ Bigham, 1993) & PFBC - Commercial \\
\hline $\mathrm{CaSO}_{4}$ & 41 & $19-47$ \\
$\mathrm{CaMg}\left(\mathrm{CO}_{3}\right)_{2}$ & NA & $17-31$ \\
$\mathrm{CaO}$ & 16 & $4-6$ \\
$\mathrm{CaCO}$ & 2 & $9-29$ \\
Periclase $(\mathrm{MgO})$ & 7 & $11-27$ \\
\hline
\end{tabular}

* Not available. 


\section{TABLE 7}

Summary of Leaching Characterization Data for PFBC By-Products, $\mu \mathrm{g} / \mathrm{L}$

\begin{tabular}{lccc}
\hline & $\mathrm{AFBC}$ & PFBC - Pilot & PFBC - Commercial \\
\hline $\mathrm{Al}$ & $<0.5$ & $0.05-0.63$ & $0.12-0.14$ \\
$\mathrm{Ca}$ & $960-1100$ & $395-710$ & $3100-3800$ \\
$\mathrm{~K}$ & $60-1350$ & $550-920$ & $3.01-21.13$ \\
$\mathrm{Mg}$ & $<4.0$ & $<4.0$ & $881.52-1351.80$ \\
$\mathrm{Na}$ & $31-79$ & $195-435$ & $1.67-9.82$ \\
$\mathrm{Zn}$ & $0.77-<0.3$ & $<0.3$ & $<0.005$ \\
$\mathrm{As}$ & $<0.5$ & $13-30$ & $20-31$ \\
$\mathrm{Cl}$ & $6-381$ & $5-170$ & $4-1580$ \\
$\mathrm{~F}$ & $<1$ & $<0.1-3.2$ & $0.6-4.9$ \\
$\mathrm{NO}$ & $<1$ & $<1$ & $\mathrm{NA}$ \\
$\mathrm{SO}_{3}$ & $113-1640$ & $1808-1440$ & $1525-2184$ \\
$\mathrm{SO}$ & $\mathrm{NA}$ & $1-21$ & $3-578$ \\
$\mathrm{Cd}$ & $\mathrm{NA}$ & $0.4-1.5$ & $0.4-1.6$ \\
$\mathrm{Cr}$ & $\mathrm{NA}$ & $26-79$ & $20-49$ \\
$\mathrm{Cu}$ & $\mathrm{NA}$ & $3-27$ & $25-69$ \\
$\mathrm{Hg}$ & $\mathrm{NA}$ & $<0.5-0.8$ & $<0.5-2$ \\
$\mathrm{Ni}$ & $\mathrm{NA}$ & $12-34$ & $13-62$ \\
$\mathrm{~Pb}$ & $\mathrm{NA}$ & $7-25$ & $6-15$ \\
\hline
\end{tabular}

* Not available.

From all the CCT commercial demonstration projects, only the Tidd demonstration has a well-documented and published set of information on the by-products generated at the commercialscale demonstration project. The three IGCC projects are all in initial phases of operation, with Wabash River having started up earliest, Tampa Electric second, and Piñon Pines only initiating commercial-scale operation in April 1997.

\subsection{Integrated Gasification Combined Cycle}

Data voluntarily submitted by the Tampa Electric IGCC Project are included in Appendix C. Similar data will be forthcoming from the other two IGCC projects, however, were not available for inclusion in this report. The data provided indicate that they have considered the issues relative to by-product management carefully by evaluating all by-products for the parameters necessary to determine hazardousness. A summary of the bulk compositional data and toxicity characteristic leaching procedure (TCLP) data is shown in Table 8. Collection of these data continues, and data from the remaining commercial-scale demonstration project will be submitted to the U.S. Environmental Protection Agency (EPA) during the comment period for the effort by EPA to address the Phase I Bevill Amendment wastes. When commercial-scale by-product data has been collected, it will also be available to EPA in electronic form through a database developed for the EPA Center for Air Toxic Metals (CATM).

\subsection{Pressurized Fluidized-Bed Combustion}

Because the Tidd CCT (PFBC) Project is completed, commercial-scale by-product characterization information is available. Table 5 compares the characteristics of AFBC by-products 
TABLE 8

Summary of Tampa Electric IGCC Project Commercial-Scale By-Product Data

\begin{tabular}{|c|c|c|c|}
\hline Bulk Chemistry, wt\% & $\begin{array}{l}\text { Average Fine } \\
\text { Boiler Slag Grab }\end{array}$ & $\begin{array}{l}\text { Average Source } \\
\text { Boiler Slag Grab }\end{array}$ & \\
\hline Silica & 50.22 & 48.86 & \\
\hline Alumina & 23.62 & 23.65 & \\
\hline Ferric Oxide & 15.99 & 17.51 & \\
\hline Calcium Oxide & 3.74 & 4.58 & \\
\hline Magnesia & 0.67 & 0.78 & \\
\hline Potassium Oxide & 1.63 & 1.96 & \\
\hline Sodium Oxide & 0.94 & 0.86 & \\
\hline Sulfur Trioxide & 0.23 & 0.45 & \\
\hline $\begin{array}{l}\text { EPA. SW } 846 \text { hetiod } \\
\text { Elements, nort? }\end{array}$ & 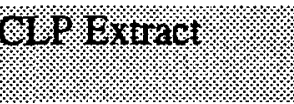 & & RORA IIIIII \\
\hline As & $<0.02$ & $<0.02$ & $\frac{5}{5}$ \\
\hline $\mathrm{Ba}$ & 0.42 & 0.32 & 100 \\
\hline $\mathrm{Cd}$ & 0.02 & 0.01 & 1 \\
\hline $\mathrm{Cr}$ & $<0.01$ & $<0.01$ & 5 \\
\hline $\mathrm{Hg}$ & $<0.01$ & $<0.01$ & 0.2 \\
\hline $\mathrm{Pb}$ & $<0.05$ & $<0.05$ & 5 \\
\hline $\mathrm{Se}$ & $<0.02$ & $<0.02$ & 1 \\
\hline
\end{tabular}

with pilot-scale PFBC by-products and commercial-scale PFBC by-products from the Tidd CCT Project. Using RCRA criteria, the data in Appendix D, summarized in Table 7 indicate that PFBC by-products would not be considered hazardous. It can be further determined from data in Appendices B and D and Table 5-7 that the by-products from pilot-scale and commercial-scale demonstration are similar in character. Commercial-scale PFBC by-products are comparable in many ways to AFBC by-products (as summarized in Tables 5-7). The pilot-scale mineralogical data not included in Table 6 because methodology used to determine the minerals was not reported, and the data cannot be confirmed. PFBC processes result in high-volume wastes that are combinations of sorbent and fly ash. Since the sorbent is generally expected to be calcium-based, the materials (both spent bed material and PFBC fly ash) have higher calcium and sulfur contents than most conventional pulverized coal combustion bottom ash and fly ash, but generally exhibit lower concentrations of many trace elements. The commercial-scale operation of the Tidd PFBC plant utilized dolomite as the sorbent, so the byproduct had a high magnesium content not indicated by pilot-scale data. It also resulted in higher sulfur capture.

\subsection{BY-PRODUCT/WASTE MANAGEMENT FOR IGCC AND PFBC}

As stated previously, by-product/waste management has been evaluated emphasizing utilization in the DOE CCT program. Management by marketing and utilization is technically feasible for the by-products/wastes described in this report, but CCT by-product/waste management decisions must include consideration of environmental and economic factors. These factors can be evaluated only on a specific process at a specific site because of the numerous variables. Each DOE 
CCT commercial-scale demonstration project is expected to consider these variables within the appropriate regulatory framework.

\subsection{Integrated Gasification Combined Cycle}

IGCC slags exhibit physical and chemical properties similar to specific coal combustion byproducts, specifically boiler slag and bottom ash, that are utilized in engineering or manufacturing applications. This is an indication that IGCC by-products can be managed through utilization rather than disposal. Table 9 compares properties of IGCC slag with these of boiler slag and bottom ash.

Utilization options noted in the literature based on characteristics of bench- and pilot-scalegenerated by-products included 1) cement and concrete production 2) numerous aggregate applications 3) fill applications and 4) soil amendments. Coal combustion byproducts are currently being successfully utilized in all of these applications that IGCC by-products can be used in the same applications indicates that regulation of these by-products should parallel that of coal combustion by-products. As reported by IEA Coal Research (Clarke, 1992), several processes and patents have been developed for the utilization of IGCC slag.

TABLE 9

Comparison of Properties of IGCC Slag, Boiler Slag, and Bottom Ash

\begin{tabular}{lccc}
\hline Chemical Component & IGCC Slag & PC* Boiler Slag & PC Bottom Ash \\
\hline $\mathrm{SiO}_{2}$ & $10-64.9$ & $40.5-53.6$ & $45.9-70.0$ \\
$\mathrm{Al}_{2} \mathrm{O}_{3}$ & $3-29.6$ & $13.8-22.7$ & $15.9-28.3$ \\
$\mathrm{Fe}_{2} \mathrm{O}_{3}$ & $0.1-25.7$ & $10.13-14.3$ & $2.0-14.3$ \\
$\mathrm{CaO}$ & $2.7-49$ & $1.4-22.4$ & $0.4-15.3$ \\
$\mathrm{MgO}$ & $0.7-7$ & $5.2-5.6$ & $1.9-5.2$ \\
$\mathrm{Na}_{2} \mathrm{O}$ & $0.3-4$ & $0.7-1.7$ & $0.6-1.0$ \\
$\mathrm{~K}_{2} \mathrm{O}$ & $<0.1-4.6$ & $0.1-1.1$ & $0.1-0.3$ \\
\hline
\end{tabular}

* Pulverized coal.

\subsection{Pressurized Fluidized-Bed Combustion}

As evidenced by numerous reports (Beeghly, 1995; Dick, 1995; Bigham and others, 1992; Bigham and others n.d.; Clarke, 1992; Smith, 1991), the management of PFBC by-products, specifically spent bed material and PFBC fly ash, is anticipated to be very similar to that for AFBC by-products because of the similarities in chemical and physical properties. FBC by-products are high volume and are generally a mixture of coal ash and sorbent. The volume of these materials that is generated makes management a particularly critical issue.

PFBC by-products are expected to be successfully utilized in many of the applications demonstrated for AFBC by-products, and many of these applications, such as soil amendment and mine reclamation, require high volumes and take advantage of the specific characteristics of FBC by-products such as high calcium content and high $\mathrm{pH}$. 
Tidd PFBC spent bed material and cyclone ash have been evaluated for beneficial uses. The by-products from the Tidd PFBC commercial demonstration had high magnesium contents because dolomite was used as the sorbent. This was beneficial for several use scenarios because the byproduct did not exhibit the exothermal, cementitious reactions frequently rated for high calcium CCBs. The land application for agriculture as a soil amendment and for mine reclamation is primarily due to the high acid-neutralizing capacity and gypsum content of these materials (Beeghly, 1995; Dick, 1995). Further, results of compressive strength, permeability, and compressibility tests indicate that the PFBC by-products are practical materials for use in highvolume engineered filled embankments, base course, and for soil reinforcement (Beeghly, 1995).

In an State of Ohio Department of Transportation project, PFBC by-product demonstrated high strength, ease of installation and, no significant change in the environment of the surroundings (Payette, 1997). The installation procedures that were followed make it clear that no special equipment or training is necessary to use the by-product. The CCT by-product generally exhibits excellent strength properties and workablity.

\subsection{REPORT SUMMARY}

The results of the review of documentation and data on the clean coal technologies IGCC and PFBC and their associated by-products performed for DOE can be summarized as follows:

- DOE and industry responded to EPA mandates to reduce emissions from energy production from fossil fuel use and developed energy and environmentally efficient technologies.

- By-product utilization was a high priority for commercial IGCC and PFBC demonstration projects, understanding that in some specific instances, disposal needs to be considered.

- Leachate data indicate that these by-products are not hazardous based on RCRA limits.

- The commercial IGCC and PFBC demonstration projects currently under way successfully worked with state agencies to permit the facilities with by-product utilization as a priority. Disposal, if required, will meet state solid waste requirements.

- Handling of CCT by-products may or may not include commingling. When co-mingling is part of the process, it is part of the process design, and by-product management options have been considered in the design phase.

- Some solid wastes generated at CCT sites, such as mill rejects, are the same as those generated at conventional coal-fired plants, and were not included in this report.

- Data indicate that CCT by-products have similar use potential to that of conventional coal combustion by-products, so similar regulatory status is warranted. 


\subsection{REFERENCES}

Beeghly, J.H,; Dick, W.A.; Wolfe, W. “ Developing Technologies for High Volume Land Application Uses of PFBC Ash," 13th International Fluidized Bed Combustion Conference ASME and EPRI, Orlando, Florida, May 7-10, 1995.

Bigham, J.M.; Fowler, R.K.; Soto, U.I.; Traina, S.J. "Mineralogy of Clean Coal Technology ByProducts," Presented at the Pittsburgh Coal Conference, Oct. 1992.

Bigham, J.; Dick, W.; Forster, L.; Hitzhusen, F.; McCoy, E.; Stenhonwer, R.; Traina, S.; Wolfe W. "Land Application of Dry FGD By-Products: Phase 1 Report," Dravo Lime Company Piitsburgh PA, The Ohio State University, Columbus OH; U.S. Geological Survey, Department of Interior, Columbus, OH, 1993.

Bigham, J.; Dick, W.; Forster, L.; Hitzhusen, F.; McCoy, E.; Stenhonwer, R.; Traina, S.; Wolfe W. "Land Application of Dry FGD By-Products: Phase 2 Report," Dravo Lime Company Piitsburgh PA, The Ohio State University, Columbus OH; U.S. Geological Survey, Department of Interior, Columbus, OH, 1996.

Clarke, L.B. "Applications for Coal-Use Residues," IEACR/50, IEA Coal Research, Nov. 1992.

Clarke, L.B. "Management of By-Products from IGCC Power Generation," IEACR/38; IEA Coal Research, May 1991.

Dick, W.A,; Sutton, P,; Stehower, R.C. "Minespoil Amendment with dry FGD By-Products: Plant Growth," Journal of Environmental Quality 24 (5) 1995, p 861-869.

Domeracki, W.F.; Bachovchin, D.M.; Crumm, C.J.; Morton, F.C. "Topping Combustor Application to the Wilsonville Advanced Power System Development Facility," Fluidized Bed Combustion - Volume 1, ASME, 1997, pp 99-105.

Douglas, J. "Breaking Through Performance Limits Beyond Steam," EPRI J. 1990, Dec., 5-11.

Eklund, A.G. "Coal Gasification Environmental Data Summary: Solid Wastes and Tar By-Products," EPA/600/7-86/015c; April 1986.

Electric Power Research Institute. "Cool Water Coal Gasification Program," final report; EPRI GSB6806, Project 1459, 1990.

Hassett, D.J.; McCarthy, G.J.; Henke,-K.R.; Korynta, E.D. "Characterization of a Lignite Ash from the METC Gasifier III: Correlations with Leaching Behavior and Mineralogy," In Fly Ash and Coal Conversion By-Products: Characterization, Utilization, and Disposal 1.; McCarthy, G.J.; Lauf, R.J., Eds.; Materials Research Society, Pittsburgh, PA, 1985.

Henderson A.K., Mann M.D., Swanson M.L. "PFBC and a New Era for Coal Rise From Mothballed Plant" Power, Ed. Jason Makansi, Pressurized Fluidized-bed Combustion Semiannual Report, EERC, April 1991, pp 103-108. 
Mahagaokar, U.; Krewinghous, A.B.; Kiszka, M.B. "Shell Coal Gasification Project: Gasification of Six Diverse Coals," EPRI report; GS-7051s, 1990.

Mann, M.D.; Galbreath, K.C.; Kalmanovitch, D.P. "The Role of Ash Chemistry and Operating Parameters on Ash Agglomeration and Deposition in FBC Systems," In Inorganic Transformations and Deposition During Combustion; Benson, S.A., Ed.; ASME: New York, 1992.

McCarthy, G.J.; Keller, L.P.; Stevenson, R.J.; Galbreath, K.C.; Steinwand, A.L. "Characterization of a Lignite Ash from the METC Gasifier, I. Mineralogy," In Proceedings of the Fly Ash and Coal Conversion By-Products: Characterization, Utilization, and Disposal I Symposium; McCarthy, G.J.; Lauf, R.J., Eds.; Materials Research Society, Pittsburgh, PA, 1985.

McClung, J.D.; Provol, S.J.; Morehead, H.T.; Dodd, A.M. "The Lakeland McIntosh Unit 4 Demonstration Project Utilizing Fopster Wheeler's Pressurized Circulating Fluidized-Bed Combustion Technology," In Fluidized Bed Combustion; Vol. 1, ASME, 1997; pp 79-86.

McClung, J.; Quandt, M.; Hemmings, J.; Moore, D. "Design and Operating Considerations for an Advanced PFBC Plant at Wilsonville," Fluidized Bed Combustion, Vol. 1, ASME, 1995; pp 107-115.

Mudd, M.J.; Stogran, H.K. "Tidd PFBC Demonstration Plant Status as of the Start of Construction," Proceedings: 1988 Seminar on Fluidized-Bed Combustion Technology for Utility Applications; EPRI GS-6118, Project 1179, pp 2-1-1 to 2-1-12, 1989.

Payette, R.M.; Wolf, W.E.; and Beegly, J. "Use of Clean Coal Combustion By-Products in Highway Repairs," Fuel, 1997 Vol. 76, No. 9, pp 749-753.

Smith, I.M. "Management of AFBC Residues," IEACR/21; IEA Coal Research, Feb. 1991.

Smoot, D.L.; Smith, P.J. Coal Combustion and Gasification; Plenum Press, New York, NY, 1985.

Stevenson, R.J.; Larson, R.A. "Characterization of a Lignite Ash From the METC Gasifier II. Scanning Electron Microscopy," In Proceedings of the Fly Ash and Coal Conversion By-Products: Characterization, Utilization, and Disposal I. Symposium; McCarthy, G.J.; Lauf, R.J., Eds.; Materials Research Society, Pittsburgh, PA, 1985.

Turner, R.R.; Lowry, P.D. "Comparison of Solid Wastes from Coal Combustion and Pilot Coal Gasification Plants," Performed by Oak Ridge National Laboratory for EPRI under EA-2867, Feb. 1983.

Wetzel, R.E.; Crawford, R.W.; Yee, W.C. "Environmental Aspects of the GKT Coal Gasification Process," In Proceedings of the Environmental Aspects of Fuel Conversion Technology VI Symposium; EPA-600/9-82-017, PB83-128181, Aug. 1982. 
Energy \&

Environmental

Research

Center

\section{APPENDIX A}

\section{PILOT-SCALE IGCC DATA}


TABLE A-1

Summary of Gasification Processes/Operating Conditions for Pilot-Scale Data (Clark 1991)

\begin{tabular}{|c|c|c|c|c|c|c|}
\hline Gasifier & Bed Type & Ash Type & Feed & Fuel** & $\begin{array}{c}\text { Pressure, } \\
\mathrm{MPa}\end{array}$ & $\begin{array}{c}\text { Reaction } \\
\text { Temperature, }{ }^{\circ} \mathrm{C}\end{array}$ \\
\hline \multicolumn{7}{|l|}{ Slagging } \\
\hline BGL (British Gas/Lurgi & Moving & Slag & Dry & $\mathrm{B} / \mathrm{SB}$ & 2.5 & $2000+$ \\
\hline Destec* & Entrained & Slag & Slurry & $\mathrm{SB} / \mathrm{L}$ & 2.2 & $1320-1430$ \\
\hline GSP (Gas Kombinat Schwarze Pumpe) & Entrained & Slag & Dry & $\mathbf{L}$ & 3.0 & $1800-2200$ \\
\hline PRENFLO (Pressurized Entrained-Flow) & Entrained & Slag & Dry & $\mathrm{B} / \mathrm{SB}$ & 3.0 & $1500-2000$ \\
\hline Shell & Entrained & Slag & Dry & $\mathrm{B} / \mathrm{SB} / \mathrm{L}$ & 3.0 & $1350-1700$ \\
\hline Texaco* & Entrained & Slag & Slurry & B & 4.1 & $1260-1450$ \\
\hline $\begin{array}{l}\text { CRIEPI (Central Research Institute of Electric } \\
\text { Power Industry - Japan) }\end{array}$ & Entrained & Slag & Dry & - & - & - \\
\hline \multicolumn{7}{|l|}{ Nonslagging: } \\
\hline HTW (High-Temperature Winkler & Fluidized & Dry & Dry & $\mathrm{L} / \mathrm{B}$ & 1.0 & $800-1000$ \\
\hline KRW (Kellogg-Rust-Westinghouse)* & Fluidized & Agglomerate & Dry & $\mathrm{B} / \mathrm{SB}$ & 2.1 & $870-1040$ \\
\hline U-Gas (Utility - Gas) & Fluidized & Agglomerate & Dry & $\mathrm{B} / \mathrm{SB}$ & $0.4-3.2$ & $950-1090$ \\
\hline
\end{tabular}

* Currently being demonstrated at commercial scale under DOE CCT program.

** $\mathrm{S}=$ subbituminous, $\mathrm{B}=$ bituminous, and $\mathrm{L}=$ lignite. 
Chemical Composition of IGCC Slag (Clark, 1991)

British Gas/Lurgi

\begin{tabular}{|c|c|c|c|c|c|c|c|c|c|c|c|}
\hline \multicolumn{2}{|c|}{ Coal Source } & \multicolumn{10}{|c|}{ All Unspecified } \\
\hline $\mathrm{SiO}_{2}$ & & 36.4 & 36.6 & & 2.735 .1 & 31.5 & 33.0 & $34.3 \quad 2$ & $27.8 \quad 37$. & $.4 \quad 29.0$ & 36.3 \\
\hline $\mathrm{TiO}_{2}$ & & - & - & & - & - & - & - & - & - & - \\
\hline $\mathrm{Al}_{2} \mathrm{O}_{3}$ & & 22.2 & 23.5 & & $8.0 \quad 24.2$ & 22.2 & 26.7 & 17.9 & $11.4 \quad 23.3$ & 29.6 & 28.0 \\
\hline $\mathrm{Fe}_{2} \mathrm{O}_{3}$ & & 0.1 & 9.0 & & 5.2 & 0.1 & 0.1 & 0.1 & 0.2 & 0.1 & 0.1 \\
\hline $\mathrm{FeO}$ & & 5.3 & 1.8 & & 0.1 & 8.1 & 3.3 & 4.9 & 3.4 & 1.4 & 0.5 \\
\hline $\mathrm{MgO}$ & & 1.2 & 2.2 & & 2.6 & 2.0 & 1.7 & 2.0 & 4.4 & 2.4 & 2.4 \\
\hline $\mathrm{CaO}$ & & 23.6 & 11.8 & & $8.9 \quad 20.8$ & 16.7 & 16.2 & 32.53 & 30.510 .5 & .935 .3 & 26.9 \\
\hline $\mathrm{Na}_{2} \mathrm{O}$ & & 1.6 & 3.3 & & 0.3 & 0.8 & 3.3 & 0.3 & 0.6 & 1.1 & 1.7 \\
\hline $\mathrm{K}_{2} \mathrm{O}$ & & 1.3 & 1.4 & & 1.3 & 1.7 & 1.0 & 1.3 & 0.3 & 0.3 & 0.9 \\
\hline \multirow[t]{2}{*}{$\mathrm{P}_{2} \mathrm{O}_{5}$} & & - & - & & - & - & - & - & - & - & - \\
\hline & \multicolumn{5}{|c|}{ CRIEPI } & \multicolumn{3}{|c|}{ Destec } & \multicolumn{3}{|c|}{ GSP } \\
\hline $\begin{array}{l}\text { Coal } \\
\text { Source }\end{array}$ & Japan & China & Cana & & $\begin{array}{l}\text { South } \\
\text { Africa }\end{array}$ & Rochell & SUFC & & \multicolumn{3}{|c|}{ Poland Germany Germany } \\
\hline$\overline{\mathrm{SiO}_{2}}$ & 53.2 & 58.7 & $\overline{64}$ & \multicolumn{2}{|r|}{58.4} & 36. & $\overline{54.8}$ & & 35.8 & $28-55$ & $10-17$ \\
\hline $\mathrm{TiO}_{2}$ & 0.8 & 1.6 & & 3 & 0.9 & 2.5 & \multicolumn{2}{|c|}{1.0} & - & - & - \\
\hline $\mathrm{Al}_{2} \mathrm{O}_{3}$ & 27.9 & 21.1 & 14 & .4 & 21.7 & 17. & \multicolumn{2}{|c|}{11.8} & 29.2 & $3-9$ & $5-7$ \\
\hline $\mathrm{Fe}_{2} \mathrm{O}_{3}$ & 5.7 & 11.7 & & .0 & 5.5 & 7.2 & \multicolumn{2}{|c|}{7.0} & - & - & - \\
\hline $\mathrm{FeO}$ & - & - & - & & - & - & \multicolumn{2}{|c|}{ - } & 8.6 & $14-28$ & $6-12$ \\
\hline $\mathrm{MgO}$ & 1.8 & 0.8 & & .1 & 1.8 & 5.2 & \multicolumn{2}{|c|}{2.0} & 3.7 & $3-7$ & $6-7$ \\
\hline $\mathrm{CaO}$ & 7.7 & 4.1 & & .7 & 9.0 & 29.5 & 27.8 & & 8.1 & $17-33$ & $43-49$ \\
\hline $\mathrm{Na}_{2} \mathrm{O}$ & 1.1 & 0.5 & & .6 & 0.7 & 0.9 & 2.6 & & 1.0 & - & $2-4$ \\
\hline $\mathrm{K}_{2} \mathrm{O}$ & 1.1 & 1.2 & & .9 & 0.8 & 0.3 & 0.1 & & 1.6 & - & $<0.1$ \\
\hline$\underline{\mathrm{P}_{2} \mathrm{O}_{5}}$ & - & - & $=$ & & - & 2. & 0.4 & & - & - & - \\
\hline & & RENF & & & & $\mathrm{Sh}$ & & & & Texaco & \\
\hline $\begin{array}{l}\text { Coal } \\
\text { Source }\end{array}$ & $\begin{array}{l}\text { Pitts. } \\
\text { No. } 8\end{array}$ & Ruhr & Ruhr & Saar & $\begin{array}{l}\text { Illinois } \\
\text { No. } 5\end{array}$ & SUFCo & SUFCo & SUFCo & $\begin{array}{cc}\text { Eastern } \\
0 \\
\text { US }\end{array}$ & $\begin{array}{c}\text { Western } \\
\text { US }\end{array}$ & Utah \\
\hline$\overline{\mathrm{SiO}_{2}}$ & 40.8 & 52.4 & 47.0 & 50.1 & 43.8 & 59.1 & 55.8 & 56.9 & 54.1 & 40.2 & $40-55$ \\
\hline $\mathrm{TiO}_{2}$ & 0.9 & 0.9 & 0.9 & 1.0 & 0.8 & 0.8 & 0.8 & 0.8 & 0.9 & 1.7 & - \\
\hline $\mathrm{Al}_{2} \mathrm{O}_{3}$ & 23.1 & 26.3 & 28.2 & 28.1 & 14.1 & 10.3 & 11.1 & 11.5 & 14.5 & 28.1 & $10-15$ \\
\hline $\mathrm{Fe}_{2} \mathrm{O}_{3}$ & 25.7 & 9.0 & 9.5 & 11.3 & 24.0 & 5.9 & 6.4 & 6.9 & 6.3 & 21.1 & $5-10$ \\
\hline $\mathrm{FeO}$ & - & - & - & - & - & - & - & - & - & - & - \\
\hline $\mathrm{MgO}$ & 0.7 & 2.5 & 3.1 & 2.4 & 1.0 & 3.1 & 3.3 & 3.2 & 2.8 & 1.2 & $2-5$ \\
\hline $\mathrm{CaO}$ & 4.9 & 2.9 & 5.5 & 2.7 & 10.4 & 18.5 & 19.4 & 18.0 & 17.2 & 4.3 & $10-15$ \\
\hline $\mathrm{Na}_{2} \mathrm{O}$ & 0.8 & 0.9 & 0.7 & 0.4 & 0.5 & 1.9 & 2.3 & 2.1 & 3.1 & 0.6 & - \\
\hline $\mathrm{K}_{2} \mathrm{O}$ & 1.4 & 4.6 & 4.0 & 3.4 & 0.9 & 0.1 & 0.2 & 0.3 & 0.8 & 2.1 & - \\
\hline $\mathrm{P}_{2} \mathrm{O}_{5}$ & 0.1 & 0.1 & 0.2 & 0.1 & 1.4 & 0.1 & 0.2 & 0.2 & 0.2 & 0.8 & - \\
\hline
\end{tabular}




\section{TABLE A-3}

Physical Properties of IGCC Slag (Clark, 1991)

\begin{tabular}{lcccccc}
\hline & BGL & Destec & GSP & PRENFLO & Shell & Texaco \\
\hline Slag & & & & & & \\
Size: $\mathrm{d}_{50}, \mathrm{~mm}$ & $1-1.5$ & $1.5-2$ & $0.5-2$ & $1-2$ & $1-2$ & $0.5-1.5$ \\
Range, mm & $<10$ & $<10$ & $<10$ & $<10$ & $<5$ & $<5$ \\
Moisture, \% & $5-15$ & 5 & - & - & 20 & $20-40$ \\
Specific Gravity & - & - & - & - & - & $2.08-2.22$ \\
Bulk Density, $\mathrm{kg} / \mathrm{m}^{3}$ & 1400 & 1400 & - & - & $1500-1600$ & $1040-1330$ \\
Max. Dry Density, kg/m & - & - & - & - & 1760 & 1430 \\
Optimum Moisture, \% & - & - & - & - & 7 & 23 \\
Carbon Content, \% & $<5$ & $<5$ & $<1$ & $<5$ & $<5$ & $<5-30$ \\
Particulates & & & & & & \\
Size, $\mu \mathrm{m}$ & - & - & $<10$ & $<100$ & $<200$ & $<100$ \\
Moisture, $\%$ & - & - & 1 & 0 & 0 & 10 \\
\hline
\end{tabular}


TABLE A-4

Leaching Characteristics of IGCC Slag (mg/L)

\begin{tabular}{|c|c|c|c|c|c|c|c|c|c|}
\hline \multirow{2}{*}{$\begin{array}{l}\text { Gasifier } \\
\text { Coal } \\
\text { Source }\end{array}$} & \multirow{2}{*}{$\begin{array}{c}\text { BGL } \\
\text { Pittsburgh } \\
\text { No. } 8 \\
\end{array}$} & \multicolumn{2}{|c|}{ PRENFLO } & \multicolumn{2}{|c|}{ GSP } & \multicolumn{4}{|c|}{ Texaco } \\
\hline & & $\begin{array}{c}\text { Pittsburgh } \\
\text { No. } 8 \\
\end{array}$ & $\begin{array}{c}\begin{array}{c}\text { Walsam Rohfein } \\
\text { Kohle }\end{array} \\
\end{array}$ & $\begin{array}{l}\text { East Elbian } \\
\text { Brown Coal }\end{array}$ & $\begin{array}{l}\text { West Elbian } \\
\text { Brown Coal }\end{array}$ & SUFCo & $\begin{array}{l}\text { Illinois } \\
\text { No. } 6 \\
\end{array}$ & $\begin{array}{c}\text { Pittsburgh } \\
\text { No. } 8 \\
\end{array}$ & Lemmingtor \\
\hline$\overline{\mathrm{Ag}}$ & 0.001 & 0.001 & $<0.001$ & - & - & $<0.002$ & $<0.002$ & $<0.002$ & $<0.022$ \\
\hline As & 0.003 & 0.001 & $<0.001$ & - & - & $<0.06$ & $<0.002$ & $<0.002$ & 0.003 \\
\hline B & 1.070 & 0.210 & $<0.1$ & - & - & - & - & - & - \\
\hline $\mathrm{Ba}$ & 0.402 & 0.030 & 0.085 & $<0.001$ & $<0.001$ & 0.32 & 0.086 & 0.086 & 0.096 \\
\hline $\mathrm{Be}$ & ND & 0.001 & $<0.001$ & - & - & - & - & - & - \\
\hline $\mathrm{Cd}$ & 0.002 & 0.001 & $<0.001$ & - & - & $<0.002$ & 0.013 & 0.003 & 0.008 \\
\hline Co & 0.025 & 0.041 & 0.0031 & $<0.001$ & $<0.001$ & - & - & - & - \\
\hline $\mathrm{Cr}$ & 0.053 & 0.0014 & 0.0013 & $<0.001$ & $<0.001$ & $<0.005$ & $<0.005$ & 0.006 & $<0.009$ \\
\hline $\mathrm{Cu}$ & 0.83 & 0.0037 & 0.0015 & $<0.001$ & $<0.001$ & - & - & - & - \\
\hline $\mathrm{Hg}$ & ND & 0.001 & $<0.001$ & - & - & $<0.001$ & $<0.001$ & $<0.001$ & $<0.001$ \\
\hline Mn & 2.06 & 0.028 & 0.0019 & $<0.001$ & $<0.001$ & - & - & - & - \\
\hline Mo & 0.003 & 0.001 & 0.0026 & - & - & - & - & - & - \\
\hline $\mathrm{Ni}$ & 0.075 & 0.190 & 0.033 & $<0.001$ & $<0.001$ & - & - & - & - \\
\hline $\mathrm{Pb}$ & 0.007 & 0.001 & $<0.001$ & - & - & 0.08 & $<0.002$ & $<0.001$ & 0.004 \\
\hline $\mathrm{Sb}$ & 0.011 & 0.001 & $<0.001$ & - & - & - & - & - & - \\
\hline $\mathrm{Se}$ & ND & 0.001 & $<0.001$ & - & - & $<0.08$ & $<0.03$ & $<0.003$ & $<0.003$ \\
\hline Sn & - & 0.001 & $<0.001$ & - & - & - & - & - & - \\
\hline TI & - & 0.010 & $<0.001$ & - & - & - & - & - & - \\
\hline V & - & 0.001 & $<0.001$ & - & - & - & - & - & - \\
\hline $\mathrm{Zn}$ & 0.110 & 0.021 & $<0.01$ & - & - & - & - & - & - \\
\hline $\begin{array}{l}\text { Leach } \\
\text { Method }\end{array}$ & EPA-EP & EPA-EP & DIN-38414-54 & $\begin{array}{c}\text { DIN-38414- } \\
54\end{array}$ & $\begin{array}{c}\text { DIN-38414- } \\
54\end{array}$ & EPA-EP & EPA-EP & EPA-EP & EPA-EP \\
\hline
\end{tabular}

EPA-EP (U.S.) - 24-hour batch leaching test with acidic leaching solution, 16:1 liquid-to-solid ratio.

DIN-38414-54 (German) - 24-hour batch (shake) leaching test with water used for leaching solution, 10:1 liquid-to-solid ratio.

ND is not detected.

Note: Data will be forthcoming for the Piñon Pine IGCC Power Plant and the Wabash River Coal Gasification Repowering Plant. 
TABLE A-5

Chemical Composition of Other IGCC By-Products Wastes PRENFLO Scrubber Filter Cake * (Clark, 1991)

\begin{tabular}{lcccc}
\hline Coal Source & Ruhr A & Ruhr B & Saar & Pittsburgh No. 8 \\
\hline Filter Cake & & & & \\
$\mathrm{SiO}_{2}$ & $56.9(1.14)$ & $59.8(1.13)$ & $55.7(1.11)$ & $50.1(1.13)$ \\
$\mathrm{TiO}_{2}$ & $1.0(1.21)$ & $0.8(0.88)$ & $0.9(1.01)$ & $1.2(1.16)$ \\
$\mathrm{Al}_{2} \mathrm{O}_{3}$ & $24.2(0.83)$ & $20.9(0.79)$ & $21.7(0.79)$ & $24.4(1.01)$ \\
$\mathrm{Fe}_{2} \mathrm{O}_{3}$ & $5.5(0.68)$ & $5.5(0.72)$ & $9.3(0.88)$ & $1.3(0.68)$ \\
$\mathrm{MgO}$ & $1.6(0.70)$ & $1.2(0.51)$ & $1.6(0.73)$ & $0.7(0.62)$ \\
$\mathrm{CaO}$ & $1.2(0.32)$ & $0.9(0.34)$ & $1.8(0.72)$ & $4.0(0.99)$ \\
$\mathrm{Na}_{2} \mathrm{O}$ & $1.6(1.72)$ & $1.5(1.48)$ & $0.7(1.76)$ & $1.6(1.55)$ \\
$\mathrm{K}_{2} \mathrm{O}$ & $7.1(1.46)$ & $7.3(1.50)$ & $5.3(1.48)$ & $2.4(1.29)$ \\
$\mathrm{P}_{2} \mathrm{O}_{5}$ & $0.8(2.57)$ & $1.1(5.42)$ & $0.6(3.02)$ & $0.5(1.61)$ \\
\hline
\end{tabular}

* Scrubber filter cake samples represent fine particulates that pass the cyclone collection system into a wet-scrubbing system and are collected on a filter.

\begin{tabular}{lccc}
\hline \multicolumn{4}{c}{ KRW Spent Bed and Ash Mixture } \\
\hline Coal Source & Ruhr & SUFCo & Unknown Coal Source \\
\hline $\mathrm{SiO}_{2}$ & 2.2 & 40.8 & 22.8 \\
$\mathrm{TiO}_{2}$ & 0.1 & - & - \\
$\mathrm{Al}_{2} \mathrm{O}_{3}$ & 1.9 & 9.4 & 11.0 \\
$\mathrm{Fe}_{2} \mathrm{O}_{3}$ & - & 4.3 & 8.5 \\
$\mathrm{MgO}$ & 3.5 & 2.5 & - \\
$\mathrm{CaO}$ & 88.4 & 31.4 & 36.5 \\
$\mathrm{Na}$ & 0.1 & 2.4 & - \\
$\mathrm{K}_{2} \mathrm{O}$ & 0.4 & 0.3 & - \\
$\mathrm{P}_{2} \mathrm{O}_{5}$ & 0.1 & - & - \\
$\mathrm{SO}_{3}$ & 0.9 & 6.1 & 19.2 \\
\hline
\end{tabular}


TABLE A-6

Chemical Composition (trace elements) of other IGCC By-Products/Wastes*

KRW Spent Bed and Ash Mixure

total Trace Element Concentrations $(\mu \mathrm{g} / \mathrm{g})$

\begin{tabular}{lc}
\hline Parameter & $<5$ \\
Antimony & 5 \\
Arsenic & 26.2 \\
Boron & 390 \\
Barium & $\leq 2$ \\
Beryllium & $\leq 5$ \\
Cadium & 43 \\
Chromium & $\leq 6$ \\
Cobalt & 38 \\
Copper & 289 \\
Fluorine & $\leq 3$ \\
Lead & 0.02 \\
Mercury & $\leq 5$ \\
Nickel & 3600 \\
Potassium & 63 \\
Scandium & $\leq 5$ \\
Selenium & $\leq 5$ \\
Silver & $\leq 5$ \\
Thallium & 2790 \\
Titanium & $\leq 7$ \\
Vandium & $\leq 8$ \\
Zinc & - \\
Hydrogen & $\leq 1$ \\
Cyanide, HCN & - \\
Hydrogen & 32 \\
Sulfide, $\mathrm{H}_{2} \mathrm{~S}$ & \\
\hline
\end{tabular}

* From Sierra Pacific, 1997. 
TABLE A-7

Physical Properties of Other IGCC By-Products*

\begin{tabular}{lc}
\hline Particle-Size Distribution of KRW Spent Bed and Ash Mixture from SUFCo Coal ${ }^{* *}$ \\
\hline Sieve Size & - \\
1 1/2 in. & - \\
$3 / 4$ in. & - \\
$1 / 2$ in. & - \\
$3 / 8$ in. & 100 \\
$4 \mathrm{M}^{* * *}$ & 98 \\
$8 \mathrm{M}$ & 81 \\
$16 \mathrm{M}$ & 41 \\
$30 \mathrm{M}$ & 15 \\
$50 \mathrm{M}$ & 4 \\
$100 \mathrm{M}$ & 2 \\
$200 \mathrm{M}$ & \\
\hline Results are reported as wt\% passing the sieve noted. \\
** From Sierra Pacific, 1987 \\
$* * * \quad$ Mesh
\end{tabular}


TABLE A-8

Leaching Characteristics of Other IGCC By-Products (mg/L) (Sierra pacific)

\begin{tabular}{|c|c|c|c|c|c|}
\hline \multirow{2}{*}{$\begin{array}{l}\text { Coal: } \\
\text { By-Product }\end{array}$} & \multicolumn{2}{|c|}{$\begin{array}{l}\text { PRENFLO } \\
\text { Pittsburgh No. } 8 \\
\text { (Clark, 1991) }\end{array}$} & \multicolumn{2}{|c|}{$\begin{array}{c}\text { PRENFLO } \\
\text { Walsam Rohfein Kohle } \\
\text { (Clark, 1991) } \\
\end{array}$} & \multirow{2}{*}{$\begin{array}{c}\text { KRW } \\
\text { SUFCo Coal } \\
\begin{array}{c}\text { Spent Bed } \\
\text { Material-Ash } \\
\text { Mixture }\end{array} \\
\end{array}$} \\
\hline & $\begin{array}{c}\text { Fine } \\
\text { Particulate }\end{array}$ & $\begin{array}{c}\text { Scrubber } \\
\text { Filter Cake }\end{array}$ & $\begin{array}{c}\text { Fine } \\
\text { Particulate }\end{array}$ & $\begin{array}{c}\text { Scrubber } \\
\text { Filter Cake }\end{array}$ & \\
\hline $\mathrm{Ag}$ & 0.001 & 0.002 & $<0.001$ & $<0.001$ & $\leq 0.005$ \\
\hline As & 0.001 & 0.0014 & 0.014 & 0.039 & 0.015 \\
\hline B & 5.54 & 2.16 & 0.66 & 0.38 & - \\
\hline $\mathrm{Ba}$ & 0.24 & 0.17 & 0.24 & 0.16 & 0.33 \\
\hline $\mathrm{Be}$ & 0.001 & 0.001 & $<0.001$ & $<0.001$ & - \\
\hline $\mathrm{Cd}$ & 0.021 & 0.054 & 0.15 & $<0.001$ & 0.02 \\
\hline Co & 0.16 & 0.23 & 0.2 & 0.022 & - \\
\hline $\mathrm{Cr}$ & 0.0016 & 0.0047 & $<0.001$ & $<0.001$ & 0.36 \\
\hline $\mathrm{Cu}$ & 0.14 & 0.0047 & 0.013 & 0.0033 & - \\
\hline $\mathrm{Hg}$ & 0.001 & 0.068 & $<0.001$ & $<0.001$ & 0.0041 \\
\hline $\mathrm{Mn}$ & 0.46 & 0.54 & 2.61 & 0.28 & - \\
\hline Mo & 0.001 & 0.001 & 0.013 & 0.046 & - \\
\hline $\mathrm{Ni}$ & 1.66 & 1.64 & 6.43 & 0.35 & - \\
\hline $\mathrm{Pb}$ & 0.001 & 0.068 & 0.0038 & $<0.001$ & $\leq 0.02$ \\
\hline $\mathrm{Sb}$ & 0.001 & 0.0014 & 0.15 & 1.52 & - \\
\hline $\mathrm{Se}$ & 0.001 & 0.001 & 0.006 & 0.013 & $\leq 0.02$ \\
\hline $\mathrm{Sn}$ & 0.001 & 0.0038 & $<0.001$ & $<0.001$ & - \\
\hline $\mathrm{TI}$ & 0.0051 & 0.0077 & 0.027 & 0.0058 & - \\
\hline V & 0.001 & 0.0049 & $<0.001$ & 0.0011 & - \\
\hline \multirow[t]{2}{*}{$\mathrm{Zn}$} & 3.19 & 13.50 & 124 & 1.33 & - \\
\hline & \multicolumn{2}{|c|}{ EPA-EP } & \multicolumn{2}{|c|}{ DIN-38414-545 } & TCLP \\
\hline
\end{tabular}

Scrubber filter cake samples represent fine particulates that pass the cyclone collection system into a wet-scrubbing system and are collected on a filter.

EPA-EP (U.S.) - 24-hour batch leaching test with acidic leaching solution, 16:1 liquid-to-solid ratio.

DIN-38414-54 (German) - 24-hour batch (shake) leaching test with water used for leaching solution, 10:1 liquid-to-solid ratio.

TCLP (U.S.) - Toxicity characteristic leaching procedure; 18-hour batch leaching procedure; acetic acid-acetate buffer leaching solution; 20:1 liquid-to-solid ratio. 


\section{TABLE A-9}

Semivolatile and Volatile Organics $(\mu \mathrm{g} / \mathrm{L})$

1,4-Dichlorobenzene

Hexachloroethane

Nitrobenzene

Hexachlorobutadiene

1, 4-Dinintrotoluene

Hexachlorobenzene

-Cresol

$\approx$ p-Cresol

2, 4, 6-Trichlorophenol

2, 4, 5-Trichlorophenol

Pentachlorophenol

Pyridine

Vinyl Chloride

1, 1-Dichlorethene

Chloroform

1, 2-Dichloroethane

2-Butanone

Carbon Tetrachloride

Benzene

Trichloroethane

Tetrachloroethane

Chlorobenzene
KRW SUFCo Coal (Sierra Pacific) Spent Bed Material-Ash Mixture

Indicated the practical quantitation limit:

$\mathrm{U}=$ Compound analyzed for, but not detected above reporting limits. Reporting limits are approximately the method detection limits for reagent water.

$\mathrm{J}$ = Indicates an estimated value when the compound is detected, but is below the practical quantitation limit (PQL).

$\mathrm{B}=$ Compound found in blank and sample. 
Energy \&

Environmental

Research

Center

APPENDIX B

PILOT-SCALE PFBC DATA 
TABLE B-1

PFBC Ash Leachate Characterization

\begin{tabular}{|c|c|c|c|c|c|}
\hline \multirow[b]{2}{*}{ Parameter } & \multicolumn{2}{|c|}{$\begin{array}{r}\text { U.S. } \\
\text { EPA EP } \\
\text { Toxicity Tests }\end{array}$} & \multicolumn{2}{|c|}{$\begin{array}{r}\text { ASTM D-3987-81 } \\
\text { Leachate Tests }\end{array}$} & \multirow{2}{*}{$\begin{array}{c}\text { Primary } \\
\text { Drinking } \\
\text { Water } \\
\text { Standards, } \\
\text { mg/l }\end{array}$} \\
\hline & $\begin{array}{c}\text { PFBC } \\
\text { Bed Ash, } \\
\text { mg/l }\end{array}$ & $\begin{array}{c}\text { PFBC } \\
\text { Fly Ash, } \\
\text { mg/l }\end{array}$ & $\begin{array}{c}\text { PFBC } \\
\text { Bed Ash', } \\
\text { mg/l }\end{array}$ & $\begin{array}{c}\text { PFBC } \\
\text { Fly Ash }{ }^{2}, \\
\text { mg/l }\end{array}$ & \\
\hline As & 0.008 & $<0.005$ & $<0.01$ & $<0.005$ & 0.05 \\
\hline $\mathrm{Ba}$ & 2.1 & 0.78 & 0.58 & 0.66 & 1.0 \\
\hline $\mathrm{Cd}$ & 0.1 & 0.04 & 0.02 & 0.012 & 0.01 \\
\hline $\mathrm{Cr}$ & 0.1 & $<0.08$ & $<0.08$ & 0.08 & 0.05 \\
\hline $\mathrm{Pb}$ & 0.22 & 0.056 & 0.03 & 0.038 & 0.05 \\
\hline $\mathrm{Hg}$ & $<0.0002$ & $<0.0002$ & 0.0002 & $<0.0002$ & 0.002 \\
\hline Se & $<0.01$ & $<0.01$ & $<0.01$ & $<0.01$ & 0.01 \\
\hline $\mathrm{Ag}$ & 0.1 & 0.06 & 0.04 & 0.04 & 0.05 \\
\hline $\mathrm{SO}_{4}$ & 2790.0 & 2180.0 & 1980.0 & 1750.0 & - \\
\hline $\mathrm{Ca}$ & 3900.0 & 1400.0 & 1100.0 & 980.0 & - \\
\hline $\mathrm{Mg}$ & 4400.0 & 720.0 & $0.4^{1}$ & $0.3^{1}$ & - \\
\hline
\end{tabular}

1 Magnesium becomes bound up as magnesium hydroxide. 
TABLE B-2

Results from TCLP Tests for RCRA Metals on Selected Combustion Products Derived from All Three Slurry Fuels

\begin{tabular}{llllcccc}
\hline & Knife River & Knife River & & & & \multicolumn{2}{c}{$\begin{array}{l}\text { Maximum } \\
\text { Concentration }\end{array}$} \\
$\mathrm{mg} / \mathrm{L}$ & $\begin{array}{l}\text { Lignite, } \\
\text { Bed Material }\end{array}$ & $\begin{array}{l}\text { Lignite, } \\
\text { Cyclone Ash }\end{array}$ & $\begin{array}{l}\text { RDF } \\
\text { Bed Material }\end{array}$ & $\begin{array}{l}\text { RDF } \\
\text { Cyclone Ash }\end{array}$ & $\begin{array}{l}\text { RDF-Lignite } \\
\text { Bed Material }\end{array}$ & $\begin{array}{l}\text { RDF-Lignite } \\
\text { Cyclone Ash }\end{array}$ & $\begin{array}{l}\text { Limits } \\
\text { Led }\end{array}$ \\
\hline $\mathrm{Ag}$ & $<0.001$ & $<0.001$ & $<0.001$ & $<0.001$ & $<0.001$ & $<0.001$ & 0.05 \\
$\mathrm{Ba}$ & 0.193 & 0.141 & 0.314 & 0.437 & 0.306 & 0.112 & 1.0 \\
$\mathrm{As}$ & $<0.01$ & 0.026 & $<0.01$ & $<0.01$ & $<0.01$ & 0.011 & 0.05 \\
$\mathrm{Cr}$ & 0.030 & 0.056 & 0.070 & 0.109 & $<0.01$ & 0.106 & 0.05 \\
$\mathrm{Cd}$ & $<0.001$ & $<0.001$ & 0.0011 & $<0.001$ & $<0.001$ & 0.0028 & 0.01 \\
$\mathrm{~Pb}$ & $<0.01$ & $<0.01$ & 0.018 & $<0.01$ & $<0.01$ & $<0.01$ & 0.05 \\
$\mathrm{Hg}$ & $<0.0001$ & $<0.0001$ & $<0.0001$ & $<0.0001$ & $<0.0001$ & $<0.0001$ & 0.002 \\
$\mathrm{Se}$ & $<0.002$ & $<0.002$ & $<0.002$ & 0.0028 & $<0.002$ & $<0.002$ & 0.01 \\
\hline
\end{tabular}




\section{TABLE B-3}

Pressurized Fluidized Bed - Bottom Ash

SEM Point Counts

Bulk Chemical Composition

\begin{tabular}{lcrrrrrr}
\hline & A & \multicolumn{1}{c}{$\mathrm{B}$} & \multicolumn{1}{c}{$\mathrm{C}$} & \multicolumn{1}{c}{$\mathrm{D}$} & \multicolumn{1}{c}{$\mathrm{E}$} & \multicolumn{1}{c}{$\mathrm{F}$} & \multicolumn{1}{c}{$\mathrm{G}$} \\
\hline $\mathrm{SiO}_{2}$ & 2.8 & 1.2 & 3.1 & 35.3 & 28.9 & 9.0 & 10.2 \\
$\mathrm{Al}_{2} \mathrm{O}_{3}$ & 0.4 & 0.0 & 0.5 & 10.5 & 9.5 & 2.4 & 2.7 \\
$\mathrm{Fe}_{2} \mathrm{O}_{3}$ & 6.4 & 0.9 & 1.6 & 12.0 & 15.9 & 4.2 & 4.8 \\
$\mathrm{TiO}_{2}$ & 0.2 & 0.1 & 0.1 & 0.5 & 0.5 & 0.2 & 0.2 \\
$\mathrm{P}_{2} \mathrm{O}_{5}$ & 0.0 & 0.1 & 0.1 & 0.0 & 0.0 & 0.0 & 0.1 \\
$\mathrm{CaO}$ & 50.0 & 56.5 & 33.7 & 20.3 & 26.4 & 35.5 & 47.6 \\
$\mathrm{MgO}$ & 32.1 & 38.6 & 26.7 & 12.6 & 14.9 & 25.3 & 33.7 \\
$\mathrm{Na}_{2} \mathrm{O}$ & 0.0 & 0.0 & 0.1 & 0.4 & 0.3 & 0.1 & 0.1 \\
$\mathrm{~K}_{2} \mathrm{O}$ & 0.1 & 0.2 & 0.1 & 1.0 & 0.5 & 0.3 & 0.3 \\
$\mathrm{SO}_{3}$ & 7.5 & 1.9 & 32.9 & 5.4 & 2.6 & 22.0 & 0.3 \\
$\mathrm{Cl}_{2} \mathrm{O}_{7}$ & 0.2 & 0.3 & 0.9 & 1.9 & 0.3 & 0.7 & 0.0 \\
$\mathrm{Cr}_{2} \mathrm{O}_{3}$ & 0.1 & 0.0 & 0.1 & 0.2 & 0.1 & 0.1 & 0.0 \\
$\mathrm{BaO}$ & 0.1 & 0.1 & 0.1 & 0.0 & 0.1 & 0.1 & 0.0 \\
\hline $\mathrm{A}$ & 0.1 & & & & &
\end{tabular}

$\mathrm{A}=$ Cumulative bulk composition of OTHER

$\mathrm{B}=$ Cumulative bulk composition of Mixed_Oxide_Rich

$\mathrm{C}=$ Cumulative bulk composition of Mixed_Sulfur_Rich

$\mathrm{D}=$ Cumulative bulk composition of Mixed_Carbon_Rich

$\mathrm{E}=$ Cumulative bulk composition of Mixed_Silicon_Rich

$\mathrm{F}=$ Cumulative bulk composition of the entire sample

$\mathrm{G}=\mathrm{SO}_{3}, \mathrm{Cl}_{2} \mathrm{O}_{7}, \mathrm{Cr}_{2} \mathrm{O}_{3}, \mathrm{BaO}$ Free composition of the entire sample 
TABLE B-4

Pressurized Fluidized Bed - ESP Fly Ash

SEM Point Counts

Bulk Chemical Composition

\begin{tabular}{lrrrrr}
\hline & \multicolumn{1}{c}{ A } & \multicolumn{1}{c}{$\mathrm{B}$} & $\mathrm{C}$ & $\mathrm{D}$ & $\mathrm{E}$ \\
\hline $\mathrm{SiO}_{2}$ & 18.3 & 39.1 & 41.4 & 25.4 & 35.1 \\
$\mathrm{Al}_{2} \mathrm{O}_{3}$ & 9.6 & 20.7 & 30.2 & 13.4 & 18.5 \\
$\mathrm{Fe}_{2} \mathrm{O}_{3}$ & 4.0 & 7.2 & 2.2 & 5.0 & 7.0 \\
$\mathrm{TiO}_{2}$ & 0.3 & 0.7 & 1.4 & 0.5 & 0.6 \\
$\mathrm{P}_{2} \mathrm{O}_{5}$ & 0.1 & 0.1 & 0.2 & 0.1 & 0.2 \\
$\mathrm{CaO}$ & 15.5 & 4.8 & 6.2 & 12.1 & 20.5 \\
$\mathrm{MgO}$ & 9.9 & 4.8 & 2.3 & 8.1 & 13.3 \\
$\mathrm{Na}_{2} \mathrm{O}$ & 0.9 & 1.1 & 0.7 & 1.0 & 1.5 \\
$\mathrm{~K}_{2} \mathrm{O}$ & 1.7 & 2.9 & 3.8 & 2.1 & 3.0 \\
$\mathrm{SO}_{3}$ & 30.8 & 8.2 & 8.9 & 23.3 & 0.3 \\
$\mathrm{Cl}_{2} \mathrm{O}_{7}$ & 8.6 & 9.9 & 2.5 & 8.9 & 0.0 \\
$\mathrm{Cr}_{2} \mathrm{O}_{3}$ & 0.1 & 0.2 & 0.2 & 0.1 & 0.0 \\
$\mathrm{BaO}$ & 0.2 & 0.1 & 0.0 & 0.2 & 0.0 \\
\hline
\end{tabular}

$\mathrm{A}=$ Cumulative bulk composition of Mixed_Sulfur_Rich

$\mathrm{B}=$ Cumulative bulk composition of Mixed_Carbon_Rich

C = Cumulative bulk composition of Mixed_Silicon_Rich

$\mathrm{D}=$ Cumulative bulk composition of the entire sample

$\mathrm{E}=\mathrm{SO}_{3}, \mathrm{Cl}_{2} \mathrm{O}_{7}, \mathrm{Cr}_{2} \mathrm{O}_{3}, \mathrm{BaO}$ Free composition of the entire sample 


\section{TABLE B-5}

Pressurized Fluidized Bed - Cyclone Ash

SEM Point Counts

Bulk Chemical Composition

\begin{tabular}{lrrrrrrr}
\hline & \multicolumn{1}{c}{ A } & \multicolumn{1}{c}{ B } & \multicolumn{1}{c}{ C } & D & E & \multicolumn{1}{c}{ F } & G \\
\hline $\mathrm{SiO}_{2}$ & 2.9 & 1.1 & 9.7 & 38.2 & 48.0 & 28.4 & 30.5 \\
$\mathrm{Al}_{2} \mathrm{O}_{3}$ & 8.7 & 0.0 & 3.3 & 23.0 & 22.9 & 11.9 & 12.8 \\
$\mathrm{Fe}_{2} \mathrm{O}_{3}$ & 15.5 & 0.9 & 2.6 & 12.9 & 11.7 & 8.4 & 9.1 \\
$\mathrm{TiO}_{2}$ & 0.1 & 0.1 & 0.2 & 0.5 & 0.8 & 0.3 & 0.4 \\
$\mathrm{P}_{2} \mathrm{O}_{5}$ & 0.0 & 0.1 & 0.1 & 0.0 & 0.0 & 0.1 & 0.1 \\
$\mathrm{CaO}$ & 40.5 & 55.4 & 27.6 & 7.2 & 7.6 & 21.5 & 27.1 \\
$\mathrm{MgO}$ & 22.3 & 39.3 & 21.0 & 5.2 & 3.7 & 14.2 & 17.8 \\
$\mathrm{Na}_{2} \mathrm{O}$ & 0.5 & 0.1 & 0.3 & 0.7 & 0.5 & 0.4 & 0.5 \\
$\mathrm{~K}_{2} \mathrm{O}$ & 1.1 & 0.1 & 0.5 & 2.3 & 2.9 & 1.3 & 1.5 \\
$\mathrm{SO}_{3}$ & 7.4 & 2.2 & 31.7 & 6.2 & 1.2 & 11.5 & 0.3 \\
$\mathrm{Cl}_{2} \mathrm{O}_{7}$ & 0.8 & 0.5 & 2.8 & 3.3 & 0.4 & 1.7 & 0.0 \\
$\mathrm{Cr}_{2} \mathrm{O}_{3}$ & 0.2 & 0.1 & 0.1 & 0.2 & 0.1 & 0.1 & 0.0 \\
$\mathrm{BaO}$ & 0.2 & 0.0 & 0.1 & 0.2 & 0.1 & 0.1 & 0.0 \\
\hline $\mathrm{A}=$
\end{tabular}

$\mathrm{A}=$ Cumulative bulk composition of OTHER

$\mathrm{B}=$ Cumulative bulk composition of Mixed Oxide Rich

$\mathrm{C}=$ Cumulative bulk composition of Mixed_Sulfur_Rich

$\mathrm{D}=$ Cumulative bulk composition of Mixed_Carbon_Rich

$\mathrm{E}=$ Cumulative bulk composition of Mixed_Silicon_Rich

$\mathrm{F}=$ Cumulative bulk composition of the entire sample

$\mathrm{G}=\mathrm{SO}_{3}, \mathrm{Cl}_{2} \mathrm{O}_{7}, \mathrm{Cr}_{2} \mathrm{O}_{3}, \mathrm{BaO}$ Free composition of the entire sample 
TABLE B-6

Pressurized Fluidized Bed Ash Mineral Composition in \%

\begin{tabular}{lccc}
\hline & Cyclone & ESP Fly & Bottom \\
\hline $\mathrm{SiO}_{2}$ & 7.2 & - & 1.2 \\
$\mathrm{Fe}_{2} \mathrm{O}_{3}$ & 2.0 & - & - \\
$\mathrm{CaO}$ & 0.4 & - & - \\
$\mathrm{MgO}$ & 0.4 & - & 0.4 \\
$\mathrm{CaCO}_{3}$ & 4.0 & - & 3.2 \\
Montmorillonite & 3.6 & - & 1.6 \\
Illite & 0.8 & 0.4 & - \\
Altered Kaolinite & 0.4 & 0.4 & - \\
Kaolinite & 4.0 & - & - \\
Dolomite & 1.6 & - & 0.8 \\
Anhydrite & 2.4 & 0.8 & 2.8 \\
Amorphous phase & 72.8 & 98.4 & 90.0 \\
\hline
\end{tabular}


TABLE B-7

Pressurized Fluidized Bed Ash Chemical Compositions in \%

\begin{tabular}{lccc}
\hline & Cyclone & ESP Fly & Bottom \\
\hline $\mathrm{SiO}_{2}$ & 20.4 & 26.5 & 5.9 \\
$\mathrm{Al}_{2} \mathrm{O}_{3}$ & 7.5 & 13.8 & 2.1 \\
$\mathrm{Fe}_{2} \mathrm{O}_{3}$ & 8.5 & 8.0 & 3.2 \\
$\mathrm{TiO}_{2}$ & 0.4 & 0.8 & 0.1 \\
$\mathrm{P}_{2} \mathrm{O}_{5}$ & - & 0.1 & - \\
$\mathrm{CaO}$ & 21.5 & 16.7 & 31 \\
$\mathrm{MgO}$ & 15.1 & 9.3 & 23.5 \\
$\mathrm{Na} 2 \mathrm{O}$ & 0.2 & 0.4 & - \\
$\mathrm{K}_{2} \mathrm{O}$ & 1.0 & 2.2 & - \\
$\mathrm{SO}_{3}$ & 10.3 & 23.7 & 8.7 \\
$\mathrm{Cl}^{1}$ & $110 \mathrm{ppb}$ & $43 \mathrm{ppb}$ & $87 \mathrm{ppb}$ \\
$\mathrm{S}^{2}$ & $104 \mathrm{ppb}$ & - & $343 \mathrm{ppb}$ \\
Unburned Carbon & 1.0 & - & 0.5 \\
$\mathrm{CO}_{3}-2$, as $\mathrm{CO}_{2}$ & 14.0 & - & 9.2 \\
Moisture & - & 1.9 & - \\
Water of Hydration & - & 1.2 & - \\
Unidentified & - & - & 15.8 \\
\hline
\end{tabular}




\section{TABLE B-8}

Trace Element Concentrations of the Input and Output Steams from a PFBC Testing

(Mojyahedi and others, 1990)

\begin{tabular}{|c|c|c|c|c|c|c|c|c|c|c|c|}
\hline & \multicolumn{2}{|c|}{ Inputs, ppm } & \multicolumn{9}{|c|}{ Outputs, ppm } \\
\hline & \multirow[b]{3}{*}{ Coal } & \multirow[b]{3}{*}{ Sorbent } & \multirow{2}{*}{\multicolumn{3}{|c|}{$\begin{array}{l}\text { Bed Pressure } \\
0.5 \mathrm{MPa}\end{array}$}} & \multirow{2}{*}{\multicolumn{3}{|c|}{$0.7 \mathrm{MPa}$}} & \multirow{2}{*}{\multicolumn{3}{|c|}{$1.0 \mathrm{MPA}$}} \\
\hline & & & & & & & & & & & \\
\hline & & & $\mathrm{BA}$ & $\mathrm{CA}$ & TF & BA & $\mathrm{CA}$ & TF & BA & $\mathrm{CA}$ & $\mathrm{TF}$ \\
\hline As & 33.0 & 11.0 & - & 257.0 & 356.0 & 137.0 & 237.0 & 358.0 & 139.0 & 257.0 & 378.0 \\
\hline $\mathrm{Cd}$ & 2.4 & 1.0 & - & 13.0 & 18.0 & 6.7 & 11.0 & 14.0 & 7.4 & 11.0 & 17.0 \\
\hline $\mathrm{Co}$ & 8.2 & 1.4 & - & 36.0 & 58.0 & 18.0 & 33.0 & 70.0 & 20.0 & 35.0 & 97.0 \\
\hline $\mathrm{Cu}$ & 154.0 & 4.2 & - & 777.0 & 802.0 & 696.0 & 618.0 & 724.0 & 438.0 & 621.0 & 871.0 \\
\hline $\mathrm{Hg}$ & 2.0 & 4.9 & - & 8.0 & 12.0 & 6.6 & 9.0 & 10.0 & 8.4 & 9.4 & 12.0 \\
\hline $\mathrm{Ni}$ & 16.0 & 3.8 & - & 86.0 & 147.0 & 53.0 & 76.0 & 189.0 & 51.0 & 75.0 & 241.0 \\
\hline $\mathrm{Pb}$ & 18.0 & 4.0 & - & 41.0 & 72.0 & 2.8 & 33.0 & 72.0 & 4.6 & 35.0 & 75.0 \\
\hline V & 28.0 & 2.5 & - & 122.0 & 210.0 & 66.0 & 122.0 & 269.0 & 84.0 & 135.0 & 302.0 \\
\hline
\end{tabular}

BA Bed Ash

CA Cyclone Ash

TF Tertiary Fines 
Energy \&

Environmental

Research

Center

\section{APPENDIX C}

\section{COMMERCIAL-SCALE IGCC DATA}




\section{TABLE C-1}

Co-burn By-Product Characterization Study Analytical Results

No Flue Injection ProcessFuel Type: 100\% Coal

Fine Boiler Fine Boiler Average Fine Course Boiler Course Boiler Average Course Course Boiler Course Boiler Average Units Slag Grab .01 Slag Grab .02 Boiler Slag Grab Slag Grab .01 Slag Grab .02 Boiler Slag Grab Slag Grab .01 Slag Grab .02 Fuel Grab

EPA Method SW 260 GC/MS Volatile Organics:

Dichlorodifluoromethane

$\mu \mathrm{g} / \mathrm{kg} \quad \mathrm{ND}$

Chloromethane

Vinyl Chloride

$\mu \mathrm{g} / \mathrm{kg}$

Bromomethane

$\mu \mathrm{g} / \mathrm{kg}$

Chloroethane

Trichiorofluoromethane

$\mu \mathrm{g} / \mathrm{kg}$

$\mu \mathrm{g} / \mathrm{kg}$

$\mu \mathrm{g} / \mathrm{kg}$

1,1-Dichloroethene

$\mu \mathrm{g} / \mathrm{kg}$

Methylene Chloride

Tert-Butylbenzenc

$\mu \mathrm{g} / \mathrm{kg}$

$\mu \mathrm{g} / \mathrm{kg}$

t-1,2-Dichioroetheue

$\mu \mathrm{g} / \mathrm{kg}$

$\mu \mathrm{g} / \mathrm{kg}$

2,2-Dichloropropane

c-1,1-Dichloroethene

$\mu \mathrm{g} / \mathrm{kg}$

$\mu \mathrm{g} / \mathrm{kg}$

Chloroform

? Bromochloromethane

1,1,1- Trichloroethane

1,1-Dichloropropene

Carbon Tetrachloride

1,2-Dichloroethane

Benzene

Dibromomethane

Trichloroethene

$\begin{array}{ll}\text { ND } & \text { ND } \\ \text { ND } & \text { ND }\end{array}$

ND
ND

ND

ND

ND

ND

ND

ND

ND

ND

$\mu \mathrm{g} / \mathrm{kg}$

$\mu \mathrm{g} / \mathrm{kg}$

$\mu \mathrm{g} / \mathrm{kg}$

$\mu \mathrm{g} / \mathrm{kg}$

$\mu \mathrm{g} / \mathrm{kg}$

$\mu \mathrm{g} / \mathrm{kg}$

$\mu \mathrm{g} / \mathrm{kg}$

$\mu \mathrm{g} / \mathrm{kg}$

1,2-Dichloropropane

Bromodichloramethane

Tetrachloroethene

Toluene

1,1,2-Trichloroethane

1,3-Dichloropropane

Dibromochlorometharre

1,2-Dibromoethane

Chlorobenzene

$1,1,1,2$ - Tetrachloroetharre

Ethylberlzene

Total Xylenes

Styrene

$\mu \mathrm{g} / \mathrm{kg}$

$\mu \mathrm{g} / \mathrm{kg}$

$\mu \mathrm{g} / \mathrm{kg}$

$\mu \mathrm{g} / \mathrm{kg}$

$\mu \mathrm{g} / \mathrm{kg}$

$\mu \mathrm{g} / \mathrm{kg}$

$\mu \mathrm{g} / \mathrm{kg}$

$\mu \mathrm{g} / \mathrm{kg}$

$\mu \mathrm{g} / \mathrm{kg}$

$\mu \mathrm{g} / \mathrm{kg}$

$\mu \mathrm{g} / \mathrm{kg}$

$\mu \mathrm{g} / \mathrm{kg}$

$\mu \mathrm{g} / \mathrm{kg}$

ND
ND
ND
ND
ND
ND
ND
ND
ND
ND
ND
ND
ND
ND
ND
ND
ND
ND
ND
ND
ND
ND
ND
ND
ND
ND
ND
ND
ND
ND
ND
ND
ND
ND

\begin{tabular}{|c|c|}
\hline ND & \\
\hline ND & \\
\hline ND & \\
\hline ND & \\
\hline ND & \\
\hline ND & \\
\hline ND & \\
\hline ND & \\
\hline ND & \\
\hline ND & \\
\hline ND & \\
\hline ND & \\
\hline ND & \\
\hline ND & \\
\hline ND & \\
\hline ND & \\
\hline ND & \\
\hline ND & \\
\hline ND & \\
\hline ND & \\
\hline ND & \\
\hline ND & . \\
\hline ND & \\
\hline ND & \\
\hline ND & \\
\hline ND & \\
\hline ND & \\
\hline ND & \\
\hline ND & \\
\hline ND & \\
\hline ND & \\
\hline ND & \\
\hline ND & \\
\hline ND & \\
\hline ND & \\
\hline
\end{tabular}

\begin{tabular}{ll} 
ND & NA \\
ND & NA \\
ND & NA \\
ND & NA \\
ND & NA \\
ND & NA \\
ND & NA \\
ND & NA \\
ND & NA \\
ND & NA \\
ND & NA \\
ND & NA \\
ND & NA \\
ND & NA \\
ND & NA \\
ND & NA \\
ND & NA \\
ND & NA \\
ND & NA \\
ND & NA \\
ND & NA \\
ND & NA \\
ND & NA \\
ND & NA \\
ND & NA \\
ND & NA \\
ND & NA \\
ND & NA \\
ND & NA \\
ND & NA \\
ND & NA \\
ND & NA \\
ND & NA \\
ND & NA \\
ND & NA \\
& \\
\hline
\end{tabular}

\begin{tabular}{|c|c|}
\hline NA & NA \\
\hline NA & NA \\
\hline NA & NA \\
\hline NA & NA \\
\hline NA & NA \\
\hline NA & NA \\
\hline NA & NA \\
\hline NA & NA \\
\hline NA & NA \\
\hline NA & NA \\
\hline NA & NA \\
\hline NA & $\mathbf{N A}$ \\
\hline NA & NA \\
\hline NA & $\mathrm{NA}$ \\
\hline NA & NA \\
\hline NA & NA \\
\hline NA & NA \\
\hline NA & NA \\
\hline NA & NA \\
\hline NA & $\mathrm{NA}$ \\
\hline NA & NA \\
\hline NA & NA \\
\hline NA & NA \\
\hline NA & NA \\
\hline NA & NA \\
\hline NA & NA \\
\hline NA & NA \\
\hline NA & NA \\
\hline NA & NA \\
\hline NA & NA \\
\hline NA & NA \\
\hline NA & NA \\
\hline NA & NA \\
\hline NA & NA \\
\hline NA & NA \\
\hline
\end{tabular}


TABLE C-2

Co-burn By-Product Characterization Study Analytical Results

No Flue Injection ProcessFuel Type: $100 \% \mathrm{Coal}$

\begin{tabular}{|c|c|c|c|c|c|c|c|c|c|c|}
\hline \multirow[b]{2}{*}{ Parameter } & \multirow[b]{2}{*}{ Units } & & & \multirow{2}{*}{$\begin{array}{c}\text { Average Fine } \\
\text { Boiler Slag } \\
\text { Grab }\end{array}$} & \multirow[b]{2}{*}{$\begin{array}{l}\text { Course Boiler } \\
\text { Slag Grab } .01 \\
\end{array}$} & \multicolumn{2}{|r|}{ Average Course } & \multirow{2}{*}{$\begin{array}{l}\text { Course Boiler } \\
\text { Slag Grab .01 }\end{array}$} & \multirow[b]{2}{*}{$\begin{array}{l}\text { Course Boiler } \\
\text { Slag Grab } .02\end{array}$} & \multirow[b]{2}{*}{$\begin{array}{c}\text { Average } \\
\text { Fuel Grab }\end{array}$} \\
\hline & & $\begin{array}{c}\text { Fine Boiler } \\
\text { Slag Grab .01 }\end{array}$ & $\begin{array}{c}\text { Fine Boiler } \\
\text { Slag Grab } .02\end{array}$ & & & $\begin{array}{l}\text { Course Boiler } \\
\text { Slag Grab .02 }\end{array}$ & $\begin{array}{c}\text { Boiler Slag } \\
\text { Grab }\end{array}$ & & & \\
\hline Isopropylbenzene & $\mu \mathrm{g} / \mathrm{kg}$ & $\mathrm{ND}$ & ND & $\mathrm{ND}$ & ND & ND & ND & NA & NA & $\mathrm{NA}$ \\
\hline Bromoform & $\mu \mathrm{g} / \mathrm{kg}$ & ND & ND & ND & ND & ND & ND & NA & NA & NA \\
\hline $1,1,2,2$ - Tetrachloroethane & $\mu \mathrm{g} / \mathrm{kg}$ & ND & ND & ND & ND & ND & ND & NA & NA & NA \\
\hline 1,2,3-Trichloropropane & $\mu \mathrm{g} / \mathrm{kg}$ & ND & ND & ND & ND & ND & ND & NA & NA & NA \\
\hline Bromobenzene & $\mu \mathrm{g} / \mathrm{kg}$ & ND & ND & ND & ND & ND & ND & NA & NA & NA \\
\hline n-Propylbenzene & $\mu \mathrm{g} / \mathrm{kg}$ & ND & ND & ND & ND & ND & ND & NA & NA & NA \\
\hline 2(hlorotoluene & $\mu \mathrm{g} / \mathrm{kg}$ & ND & ND & ND & ND & ND & ND & NA & NA & NA \\
\hline 4-Chlorotoluene & $\mu \mathrm{g} / \mathrm{kg}$ & ND & ND & ND & ND & ND & ND & NA & NA & NA \\
\hline 1,2,4- Trimethylbenzene & $\mu \mathrm{g} / \mathrm{kg}$ & ND & ND & ND & ND & ND & ND & NA & NA & NA \\
\hline $1,3,5$ - Trimethylbenzene & $\mu \mathrm{g} / \mathrm{kg}$ & ND & ND & ND & ND & ND & ND & NA & NA & NA \\
\hline sec-Butylbenzene & $\mu \mathrm{g} / \mathrm{kg}$ & ND & ND & ND & ND & ND & ND & NA & NA & NA \\
\hline p-Isopropyltoluene & $\mu \mathrm{g} / \mathrm{kg}$ & ND & ND & ND & ND & ND & ND & NA & NA & NA \\
\hline 1,3-Dichiorobenzene & $\mu \mathrm{g} / \mathrm{kg}$ & ND & ND & ND & ND & ND & ND & NA & NA & NA \\
\hline 1,4-Dichiorobenzene & $\mu \mathrm{g} / \mathrm{kg}$ & ND & ND & ND & ND & ND & ND & NA & NA & NA \\
\hline n-Butylbenzene & $\mu \mathrm{g} / \mathrm{kg}$ & ND & ND & ND & ND & ND & ND & NA & NA & NA \\
\hline 1 ,- Dichlorobenzene & $\mu \mathrm{g} / \mathrm{kg}$ & ND & ND & ND & ND & ND & ND & NA & NA & NA \\
\hline 1,2-Dibromo-3-Chloropropane & $\mu \mathrm{g} / \mathrm{kg}$ & ND & ND & ND & ND & ND & ND & NA & NA & NA \\
\hline 1,1,4-Trichlorobenzene & $\mu \mathrm{g} / \mathrm{kg}$ & ND & ND & ND & ND & ND & ND & NA & NA & NA \\
\hline Hexachlorobutuliene & $\mu \mathrm{g} / \mathrm{kg}$ & ND & ND & ND & ND & ND & ND & NA & NA & NA \\
\hline Naphthalene & $\mu \mathrm{g} / \mathrm{kg}$ & ND & ND & $\mathrm{ND}$ & ND & ND & ND & NA & NA & NA \\
\hline 1,2,3-Trichiorobenzenc & $\mu \mathrm{g} / \mathrm{kg}$ & ND & ND & ND & ND & ND & ND & NA & NA & NA \\
\hline \multicolumn{11}{|c|}{ EPA Method SW 270 GC/MS Semlvolatlle Organlcs } \\
\hline 2. Chloronaphthalene & $\mu \mathrm{g} / \mathrm{kg}$ & ND & ND & ND & ND & ND & ND & NA & NA & NA \\
\hline Bis (2chlorocthyl) ether & $\mu \mathrm{g} / \mathrm{kg}$ & ND & ND & ND & ND & ND & ND & NA & NA & NA \\
\hline Hexachlorobenzene & $\mu \mathrm{g} / \mathrm{kg}$ & ND & ND & ND & ND & ND & ND & NA & NA & NA \\
\hline 2-Chlorophenol & $\mu \mathrm{g} / \mathrm{kg}$ & ND & ND & ND & ND & ND & ND & NA & NA & NA \\
\hline Hexachlorocyclopentadiene & $\mu \mathrm{g} / \mathrm{kg}$ & ND & ND & ND & ND & ND & ND & NA & NA & NA \\
\hline Bis (2chioroisopropyl) ether & $\mu \mathrm{g} / \mathrm{kg}$ & ND & ND & ND & ND & ND & ND & NA & NA & NA \\
\hline N-Nitrosodi-N-Propylarnine & $\mu \mathrm{g} / \mathrm{kg}$ & ND & ND & ND & ND & ND & ND & NA & NA & NA \\
\hline Hexachloroethane & $\mu \mathrm{g} / \mathrm{kg}$ & ND & ND & ND & ND & ND & ND & NA & NA & NA \\
\hline Nitrobenzene & $\mu \mathrm{g} / \mathrm{kg}$ & ND & ND & ND & ND & ND & ND & NA & NA & NA \\
\hline 2- Methylphenol & $\mu \mathrm{g} / \mathrm{kg}$ & ND & ND & ND & ND & ND & ND & NA & NA & NA \\
\hline Isophorone & $\mu \mathrm{g} / \mathrm{kg}$ & ND & ND & ND & ND & ND & ND & NA & NA & NA \\
\hline Bis (2chloroethoxy) methane & $\mu \mathrm{g} / \mathrm{kg}$ & ND & ND & ND & ND & ND & ND & NA & NA & NA \\
\hline $3 \& 4$ Methylphenol & $\mu \mathrm{g} / \mathrm{kg}$ & ND & ND & ND & ND & ND & ND & NA & NA & NA \\
\hline
\end{tabular}


TABLE C-3

Co-Burn By-Product Characterization Study Analytical Results

No Flue Injection ProcessFuel Type: $100 \%$ Coal

Fine Boiler Fine Boiler Average Fine Course Boiler Course Boiler Average Course Course Boiler Course Boiler Average






\section{TABLE C-4}

Co-Burn By-Product Characterization Study Analytical Results No Flue Injection ProcessFuel Type: $100 \%$ Coal

\begin{tabular}{|c|c|c|c|c|c|c|c|c|c|c|}
\hline Parameter & Units & $\begin{array}{c}\text { Fine Boiler } \\
\text { Slag Grab .01 }\end{array}$ & $\begin{array}{c}\text { Fine Boiler } \\
\text { Slag Grab } .02\end{array}$ & $\begin{array}{c}\text { Average Fine } \\
\text { Boiler Slag } \\
\text { Grab }\end{array}$ & $\begin{array}{l}\text { Course Boiler } \\
\text { Slag Grab } 01\end{array}$ & $\begin{array}{l}\text { Course Boiler } \\
\text { Slag Grab } .02\end{array}$ & $\begin{array}{c}\text { Average } \\
\text { Course Boiler } \\
\text { Slag Grab }\end{array}$ & $\begin{array}{l}\text { Course Boiler } \\
\text { Slag Grab } .01\end{array}$ & $\begin{array}{l}\text { Course Boiler } \\
\text { Slag Grab } .02\end{array}$ & $\begin{array}{c}\text { Average } \\
\text { Fuel Grab }\end{array}$ \\
\hline 4-Chlorophenylphenyl Ether & $\mu \mathrm{g} / \mathrm{kg}$ & ND & ND & ND & ND & ND & ND & NA & NA & NA \\
\hline Dibenzo $(\mathrm{a}, \mathrm{h})$ anthracene & $\mu \mathrm{g} / \mathrm{kg}$ & ND & ND & ND & ND & ND & ND & NA & NA & NA \\
\hline 4- Nitroaniline & $\mu \mathrm{g} / \mathrm{kg}$ & ND & ND & ND & ND & ND & ND & NA & NA & NA \\
\hline Benzo $(g, h, l)$ perylene & $\mu \mathrm{g} / \mathrm{kg}$ & ND & ND & ND & ND & ND & ND & NA & NA & NA \\
\hline 2- Methyl-4, dinitrophenol & $\mu \mathrm{g} / \mathrm{kg}$ & ND & ND & ND & ND & ND & ND & NA & NA & NA \\
\hline 1,3-Dichlorobenzene & $\mu \mathrm{g} / \mathrm{kg}$ & ND & ND & ND & ND & ND & ND & NA & NA & NA \\
\hline 4- Bromophenylphenyl Ether & $\mu \mathrm{g} / \mathrm{kg}$ & ND & ND & ND & ND & ND & ND & NA & NA & NA \\
\hline 1,4- Dichlorobenzene & $\mu \mathrm{g} / \mathrm{kg}$ & ND & ND & ND & ND & ND & ND & NA & NA & NA \\
\hline 1 '-Dichlorobenzene & $\mu \mathrm{g} / \mathrm{kg}$ & ND & ND & ND & ND & ND & ND & NA & NA & NA \\
\hline 1,2,4- Trichlorobenzene & $\mu \mathrm{g} / \mathrm{kg}$ & ND & ND & ND & ND & ND & ND & NA & NA & NA \\
\hline Hexachlorobutadiene & $\mu \mathrm{g} / \mathrm{kg}$ & ND & ND & ND & ND & ND & ND & NA & NA & NA \\
\hline Naphthalene & $\mu \mathrm{g} / \mathrm{kg}$ & ND & ND & ND & ND & ND & ND & NA & NA & NA \\
\hline Dibenzofuran & $\mu \mathrm{g} / \mathrm{kg}$ & ND & ND & ND & ND & ND & ND & NA & NA & NA \\
\hline Pentachlorophenol & $\mu \mathrm{g} / \mathrm{kg}$ & ND & ND & ND & ND & ND & ND & NA & NA & NA \\
\hline 3,3-Dichlorobenzidine & $\mu \mathrm{g} / \mathrm{kg}$ & ND & ND & ND & ND & ND & ND & NA & NA & NA \\
\hline EPA Method SW-8080 Pesticides & & & & & & & & & & \\
\hline Aldrin & $\mu \mathrm{g} / \mathrm{kg}$ & ND & ND & ND & ND & ND & ND & NA & NA & NA \\
\hline Alpha-BHC & $\mu \mathrm{g} / \mathrm{kg}$ & ND & ND & ND & ND & ND & ND & NA & NA & NA \\
\hline Beta-BHC & $\mu \mathrm{g} / \mathrm{kg}$ & ND & ND & ND & ND & ND & ND & NA & NA & NA \\
\hline Gamma-BHC (Lindane) & $\mu \mathrm{g} / \mathrm{kg}$ & ND & ND & ND & ND & ND & ND & NA & NA & NA \\
\hline Delta-BHC & $\mu \mathrm{g} / \mathrm{kg}$ & ND & ND & ND & ND & ND & ND & NA & NA & NA \\
\hline Chlordane & $\mu \mathrm{g} / \mathrm{kg}$ & ND & ND & ND & ND & ND & ND & NA & NA & NA \\
\hline $4,4^{\prime}-$ DDD & $\mu \mathrm{g} / \mathrm{kg}$ & ND & ND & ND & ND & ND & ND & NA & NA & NA \\
\hline $4,4^{\prime}-\mathrm{DDE}$ & $\mu \mathrm{g} / \mathrm{kg}$ & ND & ND & ND & ND & ND & ND & NA & NA & NA \\
\hline $4,4^{\prime}-\mathrm{DDT}$ & $\mu \mathrm{g} / \mathrm{kg}$ & ND & ND & ND & ND & ND & ND & NA & NA & NA \\
\hline Dieldrin & $\mu \mathrm{g} / \mathrm{kg}$ & ND & ND & ND & ND & ND & ND & NA & NA & NA \\
\hline Endosulfan I & $\mu \mathrm{g} / \mathrm{kg}$ & ND & ND & ND & ND & ND & ND & NA & NA & NA \\
\hline Endosulfan II & $\mu \mathrm{g} / \mathrm{kg}$ & ND & ND & ND & ND & ND & ND & NA & NA & NA \\
\hline Endosulfan Sulfate & $\mu \mathrm{g} / \mathrm{kg}$ & ND & ND & ND & ND & ND & ND & NA & NA & NA \\
\hline Endrin & $\mu \mathrm{g} / \mathrm{kg}$ & ND & ND & ND & ND & ND & ND & NA & NA & NA \\
\hline Endrin Aldehyde & $\mu \mathrm{g} / \mathrm{kg}$ & ND & ND & ND & ND & ND & ND & NA & NA & NA \\
\hline Heptachlor & $\mu \mathrm{g} / \mathrm{kg}$ & ND & ND & ND & ND & ND & ND & NA & NA & NA \\
\hline Heptachlor Epoxide & $\mu \mathrm{g} / \mathrm{kg}$ & ND & ND & ND & ND & ND & ND & NA & NA & NA \\
\hline Toxaphene & $\mu \mathrm{g} / \mathrm{kg}$ & ND & ND & ND & ND & ND & ND & NA & NA & NA \\
\hline
\end{tabular}


TABLE C-5

Co-burn By-product Characterization Study Analytical Results

No Flue Injection ProcessFuel Type: $100 \%$ Coal

Fine Boiler Fine Boiler Average Fine Course Boiler Course Boiler Average Course Course Boiler Course Boiler Average

\begin{tabular}{|c|c|c|c|c|c|c|c|c|c|c|}
\hline 'arameter & & & 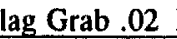 & 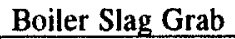 & & $\because 4$ & 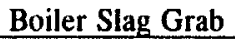 & $a_{5} J_{10}$ & NaO & Fuel Grab \\
\hline \multicolumn{11}{|l|}{ EPA Method SW-8080 PCB } \\
\hline Aroclor -1016 & $\mu \mathrm{g} / \mathrm{kg}$ & ND & ND & ND & ND & ND & ND & NA & NA & NA \\
\hline Aroclor -1221 & $\mu \mathrm{g} / \mathrm{kg}$ & ND & ND & ND & ND & ND & ND & NA & NA & NA \\
\hline Aroclor -1232 & $\mu \mathrm{g} / \mathrm{kg}$ & ND & ND & ND & ND & ND & ND & NA & NA & NA \\
\hline Aroelor -1242 & $\mu \mathrm{g} / \mathrm{kg}$ & ND & ND & ND & ND & ND & ND & NA & NA & NA \\
\hline Aroclor -1248 & $\mu \mathrm{g} / \mathrm{kg}$ & ND & ND & ND & ND & ND & ND & NA & NA & NA \\
\hline Aroclor -1254 & $\mu \mathrm{g} / \mathrm{kg}$ & ND & ND & ND & ND & ND & ND & NA & NA & NA \\
\hline Aroclor -1260 & $\mu \mathrm{g} / \mathrm{kg}$ & ND & ND & ND & ND & ND & ND & NA & NA & NA \\
\hline Aroclor -1262 & $\mu \mathrm{g} / \mathrm{kg}$ & ND & ND & ND & ND & ND & ND & NA & NA & NA \\
\hline Aroclor -1268 & $\mu \mathrm{g} / \mathrm{kg}$ & ND & ND & ND & ND & ND & ND & NA & NA & NA \\
\hline \multicolumn{11}{|c|}{ ASTM D4326-84 Standard Mineralogical Analysis } \\
\hline Silica & $\%$ & 50.04 & 50.39 & 50.22 & 49.32 & 48.40 & 48.86 & NA & NA & NA \\
\hline Alumina & $\%$ & 23.31 & 23.93 & 23.62 & 23.77 & 23.52 & 23.65 & NA & NA & NA \\
\hline Ferrie Oxide & $\%$ & 16.29 & 15.69 & 15.99 & 17.72 & 17.30 & 17.51 & NA & NA & NA \\
\hline Calcium Oxide & $\%$ & 3.79 & 3.68 & 3.74 & 4.11 & 5.04 & 4.58 & NA & $\mathrm{NA}$ & NA \\
\hline Magnesia & $\%$ & 0.65 & 0.68 & 0.67 & 0.70 & 0.86 & 0.78 & NA & NA & NA \\
\hline Potassium Oxide & $\%$ & 1.63 & 1.63 & 1.63 & 1.49 & 1.42 & 1.46 & NA & NA & NA \\
\hline Sodium Oxide & $\%$ & 0.94 & 0.94 & 0.94 & 0.84 & 0.87 & 0.86 & NA & NA & NA \\
\hline Sulfur Trioxide & $\%$ & 0.27 & 0.19 & 0.23 & 0.35 & 0.55 & 0.45 & NA & NA & NA \\
\hline \multicolumn{11}{|l|}{ Radionuclides Analysis } \\
\hline $\begin{array}{l}\text { Radium (Total alpha) } \\
\text { (SM-705 Method) }\end{array}$ & $\mathrm{pCi} / \mathrm{g}$ & 7.00 & 6.90 & 6.95 & 8.70 & 8.60 & 8.65 & NA & NA & NA \\
\hline $\begin{array}{l}\text { Umnium as U308 } \\
\text { (ASTM D2907 Method) }\end{array}$ & ppm & 7.00 & 6.00 & 6.50 & 6.00 & 6.00 & 6.00 & NA & NA & NA \\
\hline \multicolumn{11}{|c|}{ EPA SW-846 Method 1311 TCLP Extract Elements } \\
\hline Arsenic & $\mathrm{mg} / \mathrm{L}$ & $<0.02$ & $<0.02$ & $<0.02$ & $<0.02$ & $<0.02$ & $<0.02$ & NA & NA & NA \\
\hline Barium & $\mathrm{mg} / \mathrm{L}$ & 0.43 & 0.41 & 0.42 & 0.32 & 0.32 & 0.32 & NA & NA & NA \\
\hline Cadmium & $\mathrm{mg} / \mathrm{L}$ & 0.02 & $<0.01$ & 0.02 & $<.01$ & 0.01 & 0.01 & NA & $\mathrm{NA}$ & NA \\
\hline Chromium & $\mathrm{mg} / \mathrm{L}$ & $<0.01$ & $<0.01$ & $<0.01$ & $<0.01$ & $<.01$ & $<0.01$ & NA & $\mathrm{NA}$ & NA \\
\hline Lead & $\mathrm{mg} / \mathrm{L}$ & $<0.05$ & Co.05 & $<0.05$ & $<0.05$ & $<0.05$ & $<0.05$ & NA & NA & NA \\
\hline Selenium & $\mathrm{mg} / \mathrm{L}$ & $<0.02$ & $<0.02$ & $<0.02$ & $<0.02$ & $<0.02$ & $<0.02$ & NA & $\mathrm{NA}$ & NA \\
\hline Silver & $\mathrm{mg} / \mathrm{L}$ & $<0.01$ & $<0.01$ & $<0.01$ & $<0.01$ & $<0.01$ & $<0.01$ & NA & NA & NA \\
\hline \multicolumn{11}{|c|}{ ASTM Method D3683 Trace Elements } \\
\hline Arsenic & $\mu \mathrm{g} / \mathrm{g}$ & 49 & 42 & 45.5 & 30 & 21 & 25.5 & NA & $\mathrm{Na}$ & NA \\
\hline
\end{tabular}




\section{TABLE C-6}

Co-Burn By-Product Characterization Study Analytical Results

No Flue Injection ProcessFuel Type: 100\% Coal

Fine Boiler Fine Boiler Average Fine Course Boiler Course Boiler Average Course Course Boiler Course Boiler Average

\begin{tabular}{|c|c|c|c|c|c|c|c|c|c|c|}
\hline Parameter & & Irat & 1 DIa & Giao & Siag & Diag & & Diak & & \\
\hline Barium & $\frac{\mu \mathrm{g} / \mathrm{s}}{\mu \mathrm{g}}$ & 350 & 330 & 340 & 480 & 550 & 515 & NA & NA & NA \\
\hline Cadmium & $\mu \mathrm{g} / \mathrm{g}$ & $<2$ & 2 & 2 & $<2$ & $<2$ & $<2$ & NA & NA & NA \\
\hline Chromium & $\mu \mathrm{g} / \mathrm{g}$ & 100 & 74 & 87 & 270 & 380 & 325 & NA & NA & NA \\
\hline Lead & $\mu \mathrm{g} / \mathrm{g}$ & 60 & 27 & 43.50 & 53 & $<20$ & 53 & NA & NA & NA \\
\hline Mercury & $\mu \mathrm{g} / \mathrm{g}$ & $<0.02$ & 0.02 & 0.02 & $<0.02$ & 0.02 & 0.02 & NA & NA & NA \\
\hline Selenium & $\mu \mathrm{g} / \mathrm{g}$ & 22 & 19 & 20.50 & 14 & 17 & 15.50 & NA & NA & NA \\
\hline Silver & $\mu \mathrm{g} / \mathrm{g}$ & $<2$ & $<2$ & $<2$ & $<2$ & $<2$ & $<2$ & NA & NA & NA \\
\hline Thorium & $\mu \mathrm{g} / \mathrm{g}$ & 31 & 26 & 28.50 & 42 & 46 & 44 & NA & NA & NA \\
\hline \multicolumn{11}{|c|}{ ASTM Method D5373 Trace Elements } \\
\hline Carbon & $\mu \mathrm{g} / \mathrm{g}$ & 35.34 & 36.12 & 35.73 & 18.53 & 18.69 & 18.61 & NA & NA & NA \\
\hline EPA SW-846 Metl & & & & & & & & & & \\
\hline $\mathrm{pH}$ & s.u. & 4.98 & 5.56 & 5.27 & 7.15 & 7.04 & 7.10 & NA & NA & NA \\
\hline \multicolumn{11}{|c|}{ EPA Method SW-8280/8290 Dloxins } \\
\hline Total TCDD & ppb & ND & ND & ND & ND & ND & ND & NA & NA & NA \\
\hline Total PeCDD & $\mathrm{ppb}$ & ND & ND & ND & ND & ND & ND & NA & NA & NA \\
\hline Total HxCDD & $\mathrm{ppb}$ & ND & ND & ND & ND & ND & ND & NA & NA & NA \\
\hline Total HpCDD & $\mathrm{ppb}$ & ND & ND & ND & ND & ND & ND & NA & NA & NA \\
\hline \multicolumn{11}{|c|}{ EPA Method SW-8280/8290 Furans } \\
\hline Total TCDF & $\mathrm{ppb}$ & ND & ND & ND & ND & ND & ND & NA & NA & NA \\
\hline Total PeCDF & $\mathrm{ppb}$ & ND & ND & ND & ND & ND & ND & NA & NA & NA \\
\hline Total HxCDF & $\mathrm{ppb}$ & ND & ND & ND & ND & ND & ND & NA & NA & NA \\
\hline \multirow{2}{*}{\multicolumn{11}{|c|}{ X-Ray Diffraction Analysis }} \\
\hline & & & & & & & & & & \\
\hline Quartz & $\%$ & 9 & 5 & 7.00 & $<5$ & $<5$ & $<5$ & NA & NA & NA \\
\hline Mullite & $\%$ & 10 & 10 & 10.00 & 7 & 7 & 7 & NA & NA & NA \\
\hline Pymhotite & $\%$ & $<3$ & $<3$ & $<3$ & $<2$ & $<2$ & $<2$ & NA & NA & NA \\
\hline Gypsum & $\%$ & $<3$ & - & $<3$ & - & - & - & NA & NA & NA \\
\hline Amorphous & $\%$ & $70-80$ & $75-85$ & $60-70$ & $>85$ & $>85$ & $>85$ & NA & NA & NA \\
\hline Unidentified' & $\%$ & $<5$ & $<5$ & $<5$ & $<5$ & $<5$ & $<5$ & NA & NA & NA \\
\hline \multicolumn{11}{|c|}{ ASTM D5142/D5373/D4239 Proximate Analysis } \\
\hline \% Moisture & $\%$ & NA & NA & NA & NA & NA & NA & 6.01 & 482 & 5.42 \\
\hline$\%$ Ash & $\%$ & NA & NA & NA & NA & NA & NA & 7.27 & 7.62 & 7.45 \\
\hline$\%$ Volatile & $\%$ & NA & NA & NA & NA & NA & NA & 37.17 & 36.98 & 37.08 \\
\hline
\end{tabular}


TABLE C-7

Co-Burn By-Product Characterization Study Analytical Results

No Flue Injection ProcessFuel Type: 100\% Coal

Fine Boiler Fine Boiler Average Fine Course Boiler Course Boiler Average Course Course Boiler Course Boiler Average Parameter Units Slag Grab .01 Slag Grab .02 Boiler Slag Grab Slag Grab .01 Slag Grab .02 Boiler Slag Grab Slag Grab .01 Slag Grab .02 Fuel Grab



ASTM DS142/DS373/D4239 Ultimate Analysis

$\%$ Moisture

\% Carbon

\% Hydrogen

NA NA

\% Nitrogen

NA

$\%$ Sulfur

NA

$\%$ Ash

NA

NA

$\begin{array}{ll}\% & \text { NA } \\ \% & \text { NA }\end{array}$

NA

NA NA

NA

NA

NA

\% Oxygen

NA

NA

NA

NA

NA

NA

NA

NA

NA

$\begin{array}{ccc}\text { NA } & 6.01 & 4.82 \\ \text { NA } & 73.42 & 74.31\end{array}$

$\begin{array}{ll}.82 & 5.42\end{array}$

NA NA

$\begin{array}{ll}\text { NA } & \text { NA } \\ \text { NA } & \text { NA }\end{array}$

NA

NA

NA

NA

NA

$\begin{array}{llll}\text { NA } & 4.96 & 4.96 & 4.96\end{array}$

ASTM D18S7 Fusion Temperature of Ash

Reducing:

Initial Deformation

Softening

${ }^{\circ} \mathrm{F} \quad$ NA

Hemispherical

NA NA NA

NA

NA

NA

NA

NA

NA

NA

NA

1.43

Fluid $\quad{ }^{\circ} \mathrm{F} \quad$ NA

NA

NA

NA

NA NA

NA

$\begin{array}{ll}1.43 & 1.45 \\ 7.27 & 2.22\end{array}$

1.44

Initial Deformation $\quad{ }^{\circ} \mathrm{F} \quad \mathrm{NA}$

Softening

Hemispherical

Fluid

NA NA

NA NA

NA

NA

NA

7.27

2.22

2.17

$4.8 \quad 4.62$

Notes:

mg/L - Milligrams per liter.

ppm - Parts per million.

$\mathrm{pCi} / \mathrm{g}$ - Picocarries per liter per gram.

NA - Not analyzed.

$\begin{array}{ll}\text { ug/g } & \text { - Micrograrns per gram. } \\ \text { ppb } & \text { - Parts per billion. } \\ \text { s.u. } & \text { - Standard units. } \\ \text { ND } & \text { - Not detected. }\end{array}$

\begin{tabular}{llll} 
NA & 2156 & 2150 & 2153 \\
NA & 2182 & 2174 & 2178 \\
NA & 2191 & 2179 & 2185 \\
NA & 2270 & 2358 & 2314 \\
& & & \\
NA & 2420 & 2474 & 2447 \\
NA & 2439 & 2502 & 2471 \\
NA & 2459 & 2519 & 2489 \\
NA & 2500 & 2531 & 2516 \\
\hline
\end{tabular}

ug/kg- Micrograms per kilogram.

\%- Weight percent.

${ }^{\circ} \mathrm{F}$ - Degrees Fahrenheit.

*. Analyzed as received/dry basis.

1 - The detection limit for an average mineral is approximately I to 3 percent, and the analytical reproducibility is approximately equal to the square root of the amount.

2 - Amorphous material appears only as a broad elevation in the background of the $x$-ray diffraction scan so its composition cannot be determined and the estimate of its

concentration must be considered an educated guess based on the difference between the total mineral concentration and $100 \%$.

3 - Unidentified accounts for that portion of the $x$-ray diffraction scan which could not be resolved.

Source: Environmental Consulting ct Technology, Inc., 1997. 
Energy \&

Environmental

Research

Center

APPENDIX D

COMMERCIAL-SCALE PFBC DATA 
TABLE D-1

Analysis of the Tidd By-Product by Dravo Lime Company

\begin{tabular}{|c|c|c|c|c|c|c|c|c|c|c|}
\hline Geo Chemical, \% & $\begin{array}{l}\text { Tidd } \\
\text { No. } 1 \\
\end{array}$ & $\begin{array}{c}\text { Tidd } \\
\text { No. } 2 \\
\end{array}$ & $\begin{array}{c}\text { Tidd } \\
\text { No. } 3\end{array}$ & $\begin{array}{l}\text { Tidd } \\
\text { No. } 4\end{array}$ & $\begin{array}{l}\text { Tidd } \\
\text { No. } 5\end{array}$ & $\begin{array}{c}\text { Tidd } \\
\text { No. } 6\end{array}$ & $\begin{array}{c}\text { Tidd } \\
\text { No. } 7\end{array}$ & $\begin{array}{l}\text { Tidd } \\
\text { No. } 8\end{array}$ & $\begin{array}{c}\text { Tidd } \\
\text { No. } 9\end{array}$ & $\begin{array}{c}\text { Tidd } \\
\text { No. } 10\end{array}$ \\
\hline $\mathrm{CaO}$ & & 22.13 & & & & & & 21.3 & & 19.4 \\
\hline $\mathrm{MgO}$ & & 14.38 & & & & & & 13.68 & & 10.61 \\
\hline $\mathrm{SiO}_{2}$ & & 19.93 & & & & & & 21.55 & & 23.76 \\
\hline $\mathrm{Fe}_{2} \mathrm{O}_{3}$ & & 9.02 & & & & & & 10.04 & & 13.28 \\
\hline $\mathrm{Al}_{2} \mathrm{O}_{3}$ & & 7.75 & & & & & & 8.82 & & 11.6 \\
\hline $\mathrm{CO}_{2}$ & & 12.57 & & & & & & 8.6 & & 8.77 \\
\hline Total Sulfur as $\mathbf{S}$ & & 4.59 & & & & & & 5.13 & & 3.7 \\
\hline $\mathrm{SO}_{3}$ & & 10.6 & & & & & & 12.46 & & 8.69 \\
\hline $\begin{array}{l}\mathrm{SO}_{2} \\
\mathrm{LOI} @ 600^{\circ} \mathrm{C}\end{array}$ & & 0.69 & & $\cdot$ & & & & 0.28 & & 0.44 \\
\hline LOI @ $1100^{\circ} \mathrm{C}$ & & 13.54 & & & & & & 9.85 & & 10.3 \\
\hline Total of Elements Determined & & 98.04 & & & & & & 97.98 & & 98.08 \\
\hline Reactivity & & & & & & & & & & \\
\hline Temperature Rise ${ }^{\circ} \mathrm{F}$ & 2 & 2 & 11 & 5 & 2 & 4 & 9 & 11 & 5 & 2 \\
\hline Calc. Carb. Equiv., $\% \mathrm{CaCO}_{3}$ & 53.8 & 53.4 & 45.9 & 52.0 & 58.8 & 52.8 & 61.2 & 51.2 & 54 & 43.3 \\
\hline Available Lime Index, \% CaO & 0.5 & 1.0 & 1.1 & 1.0 & 0.98 & 0.72 & 1.06 & 0.64 & 1.2 & 0.9 \\
\hline \multirow[t]{2}{*}{ PH (soil) } & 10.02 & 11.92 & 11.03 & 11.91 & 11.70 & 10.53 & 12.0 & 11.9 & 12 & 11.72 \\
\hline & $@ 23^{\circ} \mathrm{C}$ & $@ 22^{\circ} \mathrm{C}$ & $@ 22^{\circ} \mathrm{C}$ & @ $22^{\circ} \mathrm{C}$ & @ $22^{\circ} \mathrm{C}$ & $@ 22^{\circ} \mathrm{C}$ & @ $22^{\circ} \mathrm{C}$ & & & \\
\hline Mixed Ratio (lbs/gal) & 25 & 25 & 20 & 20 & 20 & 20 & 18 & 18 & 18 & 20 \\
\hline \multicolumn{11}{|l|}{ Physical Properties } \\
\hline Specific Gravity, g/cc & 2.85 & 2.88 & 2.87 & 2.88 & 2.83 & 2.79 & 2.79 & 2.8 & 2.81 & 2.8 \\
\hline Bulk Density (Loose), $\mathrm{lb} / \mathrm{ft}^{3}$ & 58 & 64 & 60 & 60 & 58 & 55 & 60 & 62 & 60 & 54 \\
\hline Bulk Density (Tamped), $\mathrm{lb} / \mathrm{ft}^{3}$ & 67 & 70 & 72 & 70 & 69 & 65 & 73 & 74 & 74 & 63 \\
\hline Blaine Fineness, $\mathrm{cm}^{2} / \mathrm{g}$ & 6150 & 5610 & 5580 & 5480 & 5270 & 6120 & 5370 & 5410 & 5310 & 5580 \\
\hline Passing 200 Mesh, \% & 91 & 92 & 81 & 89 & 86 & 83 & 90 & 87 & 90 & 86 \\
\hline Passing 325 Mesh, \% & 85 & 85 & 73 & 83 & 82 & 77 & 81 & 79 & 81 & 79 \\
\hline Specific Surface Area, $\mathrm{m}^{2} / \mathrm{g}$ & & 2.65 & & & & & & 2.66 & & 3.47 \\
\hline \multicolumn{11}{|l|}{ Particle Size Distribution: } \\
\hline Passing 80 Mesh, \% & & 94 & & & & & & 93.7 & & 94.9 \\
\hline $10 \%$ passing, $\mu$ & & 2.87 & & & & & & 2.28 & & 2.6 \\
\hline $50 \%$ passing, $\mu$ & & 13.39 & & & & & & 9.09 & & 10.36 \\
\hline $90 \%$ passing, $\mu$ & & 58.33 & & & & & & 53.35 & & 54.78 \\
\hline Average Particle Size (MV), $\mu$ & & 23.6 & & & & & & 20.08 & & 20.49 \\
\hline
\end{tabular}




\section{TABLE D-2}

Metals Analysis of All the by-Products Received at Pitt RCRA Limit

\begin{tabular}{ccccccc}
\hline & Property & Units & Current & Tidd No. 2 & Tidd No.8 & Tidd No. 10 \\
\hline TCLP Metals & Antimony (Sb) & $\mathrm{mg} / \mathrm{L}$ & - & 0.0219 & & \\
& Arsenic(As) & $\mathrm{mg} / \mathrm{L}$ & 5.0 & $<0.1$ & & \\
Barium (Ba) & $\mathrm{mg} / \mathrm{L}$ & 100.0 & $<5.0$ & 0.501 & 0.501 \\
Beryllium (BQ) & $\mathrm{mg} / \mathrm{L}$ & - & $<0.001$ & $<0.001$ & $<0.001$ \\
Cadmium (Cd) & $\mathrm{mg} / \mathrm{L}$ & 1.0 & $<0.1$ & $<0.05$ & $<0.05$ \\
Chromium (Cr) & $\mathrm{mg} / \mathrm{L}$ & 5.0 & $<0.01$ & $<0.05$ & $<0.05$ \\
Copper (Cu) & $\mathrm{mg} / \mathrm{L}$ & - & $<1.0$ & & \\
Lead (Pb) & $\mathrm{mg} / \mathrm{L}$ & 5.0 & $<0.1$ & $<0.5$ & $<0.5$ \\
Mercury (Hg) & $\mathrm{mg} / \mathrm{L}$ & 0.2 & $<0.01$ & & \\
Nickel (Ni) & $\mathrm{mg} / \mathrm{L}$ & - & $<0.1$ & $<0.3$ & $<0.3$ \\
Selenium (Se) & $\mathrm{mg} / \mathrm{L}$ & 1.0 & $<0.1$ & & \\
Silver (Ag) & $\mathrm{mg} / \mathrm{L}$ & 5.0 & $<0.1$ & $<0.05$ & $<0.05$ \\
Thallium (Th) & $\mathrm{mg} / \mathrm{L}$ & - & $<0.005$ & $<0.005$ & $<0.005$ \\
Vanadlum (V) & $\mathrm{mg} / \mathrm{L}$ & - & 0.0128 & 0.0278 & 0.0296 \\
Zinc (Zn) & $\mathrm{mg} / \mathrm{L}$ & - & $<1.0$ & $<0.05$ & $<0.06$ \\
Antimony (Sb) & $\mathrm{mg} / \mathrm{L}$ & & $<0.020$ & $<0.020$ & $<0.020$ \\
Arsenic(As) & $\mathrm{mg} / \mathrm{L}$ & & & & \\
Barium (Ba) & $\mathrm{mg} / \mathrm{L}$ & & 0.645 & 0.402 & 0.456 \\
Beryllium (BQ) & $\mathrm{mg} / \mathrm{L}$ & & $<0.001$ & $<0.001$ & $<0.001$ \\
Cadmium (Cd) & $\mathrm{mg} / \mathrm{L}$ & & $<0.05$ & $<0.05$ & $<0.05$ \\
Chromium (Cr) & $\mathrm{mg} / \mathrm{L}$ & & $<0.50$ & $<0.05$ & $<0.05$ \\
Copper (Cu) & $\mathrm{mg} / \mathrm{L}$ & & $<0.20$ & & \\
Lead (Pb) & $\mathrm{mg} / \mathrm{L}$ & & $<1.00$ & $<0.5$ & $<0.5$ \\
Mercury (Hg) & $\mathrm{mg} / \mathrm{L}$ & & & & \\
Nickel (Ni) & $\mathrm{mg} / \mathrm{L}$ & & $<0.3$ & $<0.3$ & $<0.3$ \\
Selenium (Se) & $\mathrm{mg} / \mathrm{L}$ & & $<0.05$ & $<0.05$ & $<0.05$ \\
Silver (Ag) & $\mathrm{mg} / \mathrm{L}$ & & $<0.05$ & $<0.005$ \\
Thallium (Th) & $\mathrm{mg} / \mathrm{L}$ & & $<0.005$ & $<0.005$ & $<0.0189$ \\
Vanadlum (V) & $\mathrm{mg} / \mathrm{L}$ & & $<0.010$ & 0.0182 & 0.0189 \\
Zinc (Zn) & $\mathrm{mg} / \mathrm{L}$ & & $<0.05$ & 0.05 & 0.05 \\
\hline
\end{tabular}

BDAT Standards do not apply to shaded areas.

Blank spaces indicate samples which have yet to be analyzed. 


\section{TABLE D-3}

Mineralogical Composition of Dry FGD By-Products (WL \%) from Tidd PFBC Plant (Bigham 1993)

\begin{tabular}{lcccccccc}
\hline Date & Sample & $\mathrm{CaSO}_{4}$ & $\mathrm{CaMg}\left(\mathrm{CO}_{3}\right)_{2}$ & $\mathrm{CaO}$ & $\mathrm{CaCO}_{3}$ & $\mathrm{MgO}$ & Fly Ash & Total \\
\hline $08 / 28 / 91$ & $\begin{array}{c}\text { TID-FLB-01 } \\
\text { (cyclone) }\end{array}$ & 19 & 31 & & 9 & 11 & 13 & 103 \\
$08 / 28 / 91$ & TID-FLB-02 (bed) & 36 & & 4 & 29 & 26 & 10 & 105 \\
$09 / 16 / 91$ & $\begin{array}{c}\text { TID-FLB-03 } \\
\text { (cyclone) }\end{array}$ & 22 & 25 & & 12 & 12 & 32 & 103 \\
$09 / 16 / 91$ & TID-FLB-04 (bed) & 36 & & 4 & 27 & 27 & 10 & 104 \\
$09 / 16 / 91$ & TID-FLB-05 (ESP) & 46 & 17 & & & & 40 & 103 \\
$03 / 06 / 91$ & TID-FLB-06 & 22 & 17 & & 13 & 18 & 40 & 110 \\
& $\quad$ (cyclone) & & & & & & & \\
$03 / 06 / 91$ & TID-FLB-07 (bed) & 47 & & 6 & 17 & 26 & 11 & 107 \\
\hline
\end{tabular}

Quartz $\left(\mathrm{SiO}_{2}\right)$ and hermatite $\left(\mathrm{Fe}_{2} \mathrm{O}_{3}\right)$ were also identified as present in most of these samples and were likely a component of the fly ash. 
Leachate Tests of Tidd PFBC Samples (Brigham 1993)

(03 = cyclone ash, $04=$ bed ash)

ASTM Distilled Water Extraction (18 4 20:1 water FGD)

TCLP Acetic Acid Extraction (18 h, 20:1 acid FGD)

\begin{tabular}{|c|c|c|c|c|c|c|c|c|c|}
\hline \multirow[t]{2}{*}{ Sample } & & \multicolumn{2}{|c|}{ TID-FLB-03 (cyclone) } & \multicolumn{2}{|c|}{$\begin{array}{l}\text { TID-FLB-04 } \\
\text { (bed) }\end{array}$} & \multicolumn{2}{|c|}{$\begin{array}{c}\text { TID-FLB-05 } \\
\text { (ESP) }\end{array}$} & \multirow{3}{*}{$\begin{array}{l}\text { RCRA } \\
\text { Limits }\end{array}$} & \multirow{2}{*}{$\begin{array}{c}\text { Primary } \\
\text { Drinking } \\
\text { Water } \\
\text { Standards }\end{array}$} \\
\hline & & ASTM & TCLP & ASTM & TCLP & ASTM & TCLP & & \\
\hline Parameter & & & & & & & & & \\
\hline $\mathrm{pH}^{* *}$ & & 11.42 & 9.58 & 11.77 & 9.61 & 8.44 & NA & & \\
\hline $\begin{array}{l}\text { TDS } \\
(\mathrm{MG} / \mathrm{L})^{* * *}\end{array}$ & & 3136 & 12870 & 5154 & 11980 & 9044 & NA & & \\
\hline $\mathrm{Ag}$ & $\mathrm{mg} / \mathrm{L}$ & $<0.005$ & $<0.011$ & $<0.005$ & $<0.011$ & - & NA & 5 & 0.05 \\
\hline $\mathrm{Al}$ & $\mathrm{mg} / \mathrm{L}$ & $<0.049$ & 0.12 & $<0.049$ & 0.14 & $<0.11$ & NA & & \\
\hline As & $\mathrm{mg} / \mathrm{L}$ & $<0.005^{*}$ & $<0.005$ & $<0.005^{*}$ & $<0.005$ & 0.080 & NA & 5 & 0.05 \\
\hline B & $\mathrm{mg} / \mathrm{L}$ & 0.832 & 0.767 & 0.209 & 0.543 & 1.15 & NA & & \\
\hline $\mathrm{Ba}$ & $\mathrm{mg} / \mathrm{L}$ & 0.166 & 0.141 & 0.202 & 0.141 & 0.11 & NA & 100 & 1 \\
\hline $\mathrm{Be}$ & $\mathrm{mg} / \mathrm{L}$ & $<0.002$ & $<0.002$ & $<0.002$ & $<0.002$ & $<0.002$ & NA & & \\
\hline $\mathrm{Ca}$ & $\mathrm{mg} / \mathrm{L}$ & 844.45 & 1382.77 & 1139.57 & 1741.10 & 558.7 & NA & & \\
\hline $\mathrm{Cd}$ & $\mathrm{mg} / \mathrm{L}$ & $<0.001 *$ & $<0.003$ & $<0.001 *$ & $<0.003$ & $<0.003$ & NA & 1 & 0.01 \\
\hline Co & $\mathrm{mg} / \mathrm{L}$ & 0.02 & 0.026 & $<0.01$ & 0.017 & 0.02 & NA & & \\
\hline $\mathrm{Cr}$ & $\mathrm{mg} / \mathrm{L}$ & $<0.005$ & 0.011 & $<0.005$ & $<0.005$ & 0.020 & NA & 5 & 0.05 \\
\hline $\mathrm{Cu}$ & $\mathrm{mg} / \mathrm{L}$ & $<0.007$ & $<0.007$ & $<0.007$ & $<0.007$ & $<0.009$ & NA & & \\
\hline $\mathrm{Fe}$ & $\mathrm{mg} / \mathrm{L}$ & $<0.01$ & $<0.01$ & $<0.01$ & $<0.01$ & 0.02 & NA & & \\
\hline $\mathrm{Hg}$ & $\mathrm{mg} / \mathrm{L}$ & $<0.0002^{*}$ & $<0.0002^{*}$ & $<0.0002^{*}$ & $<0.0002 *$ & $<0.04$ & NA & 0.2 & 0.002 \\
\hline $\mathrm{K}$ & $\mathrm{mg} / \mathrm{L}$ & 21.68 & 21.13 & 3.43 & 3.01 & 231.64 & NA & & \\
\hline $\mathrm{Li}$ & $\mathrm{mg} / \mathrm{L}$ & 0.133 & 0.178 & $<0.030$ & 0.073 & 1.20 & NA & & \\
\hline $\mathrm{Mg}$ & $\mathrm{mg} / \mathrm{L}$ & 0.19 & 1351.80 & 0.09 & 881.52 & 1349.70 & NA & & \\
\hline $\mathrm{Mn}$ & $\mathrm{mg} / \mathrm{L}$ & $<0.053$ & $<0.001$ & $<0.053$ & $<0.001$ & $<0.053$ & NA & & \\
\hline Mo & $\mathrm{mg} / \mathrm{L}$ & 0.033 & 0.025 & 0.035 & 0.031 & 0.190 & NA & & \\
\hline $\mathrm{NA}$ & $\mathrm{mg} / \mathrm{L}$ & 8.26 & 9.82 & 1.26 & 1.67 & 107.29 & NA & & \\
\hline $\mathrm{Ni}$ & $\mathrm{mg} / \mathrm{L}$ & $<0.010$ & $<0.010$ & $<0.010$ & $<0.010$ & $<0.010$ & NA & & \\
\hline $\mathbf{P}$ & $\mathrm{mg} / \mathrm{L}$ & $<0.011$ & $<0.12$ & $<0.011$ & $<0.12$ & $<0.011$ & NA & & \\
\hline $\mathrm{Pb}$ & $\mathrm{mg} / \mathrm{L}$ & $<0.001$ & $<0.001$ & $<0.001$ & $<0.001$ & $<0.093$ & NA & 5 & 0.05 \\
\hline$S$ & $\mathrm{mg} / \mathrm{L}$ & 654.3 & 978.99 & 641.7 & 736.65 & 1972.8 & NA & & \\
\hline $\mathrm{Sb}$ & $\mathrm{mg} / \mathrm{L}$ & $<0.060$ & $<0.060$ & $<0.060$ & $<0.060$ & $<0.060$ & NA & & \\
\hline $\mathrm{Se}$ & $\mathrm{mg} / \mathrm{L}$ & $<0.005^{*}$ & $<0.005$ & $<0.005^{*}$ & $<0.005^{*}$ & 0.30 & NA & 1 & 0.01 \\
\hline $\mathrm{Si}$ & $\mathrm{mg} / \mathrm{L}$ & 1.261 & 0.33 & 0.337 & 0.31 & 3.076 & NA & & \\
\hline $\mathrm{Sr}$ & $\mathrm{mg} / \mathrm{L}$ & 0.66 & 1.205 & 0.61 & 0.833 & 2.03 & NA & & \\
\hline $\mathrm{V}$ & $\mathrm{mg} / \mathrm{L}$ & $<0.006$ & 0.022 & $<0.006$ & 0.024 & 0.43 & NA & & \\
\hline $\mathrm{Zn}$ & $\mathrm{mg} / \mathrm{L}$ & $<0.006$ & $<0.005$ & $<0.006$ & $<0.005$ & 0.017 & NA & & \\
\hline $\mathrm{Cl}$ & $\mathrm{mg} / \mathrm{L}$ & 7.9 & 19.6 & 3.2 & 28.5 & 3.9 & NA & & \\
\hline$F$ & $\mathrm{mg} / \mathrm{L}$ & 2.8 & & 2.3 & & 5.4 & NA & & \\
\hline $\mathrm{SO}_{4}$ & $\mathrm{mg} / \mathrm{L}$ & 1699 & 2795.2 & 1569 & 2264.8 & 5887 & NA & & \\
\hline
\end{tabular}


TABLE D-5

Characterization of LIMB, PFBC, and Sewage Sludge Amendments

\begin{tabular}{|c|c|c|c|}
\hline Parameter & LIMB* $^{*}$ & PFBC & Sewage Sludge \\
\hline Particle Size, $\mathrm{g} \mathrm{kg}^{-1}$ & & & $\mathrm{NA}^{1}$ \\
\hline Sand, $0.05-2 \mathrm{~mm}$ & 0 & 255 & \\
\hline Silt, $2-50 \mu \mathrm{m}$ & 900 & 741 & \\
\hline Clay, $<2 \mu \mathrm{m}$ & 100 & 4 & \\
\hline Mineralogy, $\mathrm{g} \mathrm{kg}^{-1}$ & & & NA \\
\hline Anhydrite, $\mathrm{CaSO}^{4}$ & 250 & 220 & \\
\hline Calcite, $\mathrm{CaCO}_{3}$ & 150 & 110 & \\
\hline Dolomite, $\mathrm{CaMg}\left(\mathrm{CO}_{3}\right)_{2}$ & $\mathrm{ND}^{2}$ & 230 & \\
\hline Lime, $\mathrm{CaO}$ & 210 & ND & \\
\hline Portlandite, $\mathrm{Ca}(\mathrm{OH})_{2}$ & 50 & ND & \\
\hline Periclase, MgO & ND & 130 & \\
\hline Fly Ash & 300 & 320 & \\
\hline $\mathrm{CaCO}_{3}$, equivalency ${ }^{3}$ & 0.59 & 0.60 & 0 \\
\hline $\mathrm{pH}(1: 1$, water $)$ & 12.5 & 10.5 & 6.5 \\
\hline \multicolumn{4}{|l|}{ Total Chemical Analysis } \\
\hline \multicolumn{4}{|l|}{ Major Elements, $\mathrm{g} \mathrm{kg}^{-1}$} \\
\hline Al & 35.2 & 39.3 & 34.0 \\
\hline $\mathrm{Ba}$ & 0.3 & 0.2 & 0.1 \\
\hline C (Organic) & NA & NA & 312 \\
\hline $\mathrm{CA}$ & 360 & 175 & 27.6 \\
\hline $\mathrm{Fe}$ & 55.6 & 51.7 & 12.4 \\
\hline K & 9.1 & 5.0 & 1.5 \\
\hline $\mathrm{Mg}$ & 6.0 & 106 & 3.4 \\
\hline $\mathbf{N}$ & NA & NA & 38 \\
\hline $\mathrm{Na}$ & 3.3 & 10.3 & 0.7 \\
\hline $\mathbf{P}$ & 0.2 & 0.2 & 17.8 \\
\hline$S$ & 57.7 & 52.1 & 14.1 \\
\hline $\mathrm{Si}$ & 65.8 & 72.4 & NA \\
\hline \multicolumn{4}{|l|}{ Trace Elements, $\mathrm{mg} \mathrm{kg}^{-1}$} \\
\hline As & 55.1 & 75.0 & $<0.01$ \\
\hline B & 233.1 & 171.2 & 31.1 \\
\hline $\mathrm{Cd}$ & 1.0 & 1.9 & 6.3 \\
\hline $\mathrm{Cr}$ & 28.0 & 36.9 & 315.2 \\
\hline $\mathrm{Cu}$ & 21.0 & 52.5 & 1174 \\
\hline $\mathrm{Pb}$ & 16.0 & 16.0 & 16.1 \\
\hline Mo & 5.9 & 6.6 & 11.2 \\
\hline $\mathrm{Ni}$ & 31.1 & 52.1 & 166.4 \\
\hline $\mathrm{Se}$ & 8.1 & 5.6 & $<0.3$ \\
\hline $\mathrm{Zn}$ & 86.0 & 74.0 & 1494 \\
\hline
\end{tabular}

1 Not analyzed.

2 Not detected.

3 Neutralizing capacity expressed as a fraction of the neutralizing potential of $\mathrm{CaCO}_{3}$.

* LIMB is limestone injection multi phase burner which is another CCT not presented in this report. The LIMB data is presented for comparison purposes only. 


\section{TABLE D-6}

Trrace element Composition of final leachates Collected from Pots of Wooster Soil Amended with LIMB and PFBC By-Products and Planted with alfalfa and Fescue

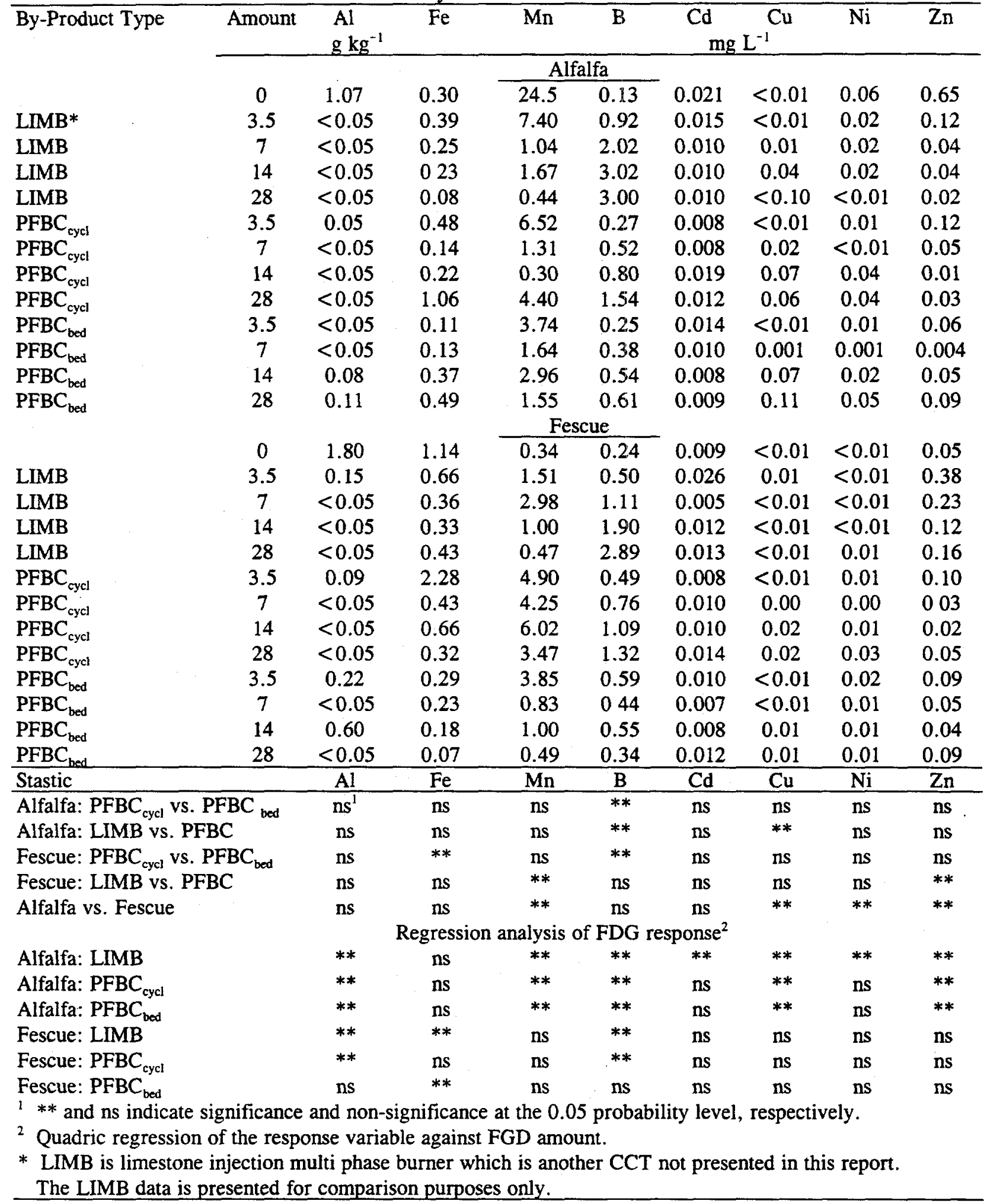

